\title{
Maria Gaetana Agnesi: Mathematics and the Making of the Catholic Enlightenment
}

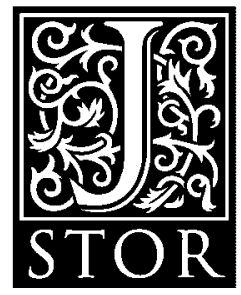

\author{
Massimo Mazzotti \\ Isis, Vol. 92, No. 4 (Dec., 2001), 657-683.
}

Stable URL:

http://links.jstor.org/sici?sici=0021-1753\%28200112\%2992\%3A4\%3C657\%3AMGAMAT\%3E2.0.CO\%3B2-D

Your use of the JSTOR archive indicates your acceptance of JSTOR's Terms and Conditions of Use, available at http://uk.jstor.org/about/terms.html. JSTOR's Terms and Conditions of Use provides, in part, that unless you have obtained prior permission, you may not download an entire issue of a journal or multiple copies of articles, and you may use content in the JSTOR archive only for your personal, non-commercial use.

Each copy of any part of a JSTOR transmission must contain the same copyright notice that appears on the screen or printed page of such transmission.

Isis is published by The University of Chicago Press. Please contact the publisher for further permissions regarding the use of this work. Publisher contact information may be obtained at http://uk.jstor.org/journals/ucpress.html.

Isis

(C2001 The History of Science Society

JSTOR and the JSTOR logo are trademarks of JSTOR, and are Registered in the U.S. Patent and Trademark Office. For more information on JSTOR contact jstor-info@umich.edu.

(C)2003 JSTOR 


\title{
Maria Gaetana Agnesi
}

\author{
Mathematics and the Making of \\ the Catholic Enlightenment
}

\author{
By Massimo Mazzotti*
}

\begin{abstract}
Maria Gaetana Agnesi (1718-1799) is known as the author of a textbook on calculus that appeared in Milan in 1748. For the first time a woman was able to establish herself as a legitimate mathematician and publish her work. This essay reconstructs the religious and scientific culture in which the textbook originated and considers lesser-known aspects of Agnesi's life and thought. It argues that Agnesi was a principal exponent of the "Catholic Enlightenment" in Italy and that her spiritual practice, pious activity, and innovative pedagogical ideas profoundly shaped her approach to mathematics. The study suggests that the reformist culture of the Catholic Enlightenment provided the conditions that enabled a few talented women to access privileged forms of knowledge and social life; it may be one factor that accounts for the unusual presence of learned women in Italian scientific institutions during the early eighteenth century.
\end{abstract}

TN THE PALEO-CHRISTIAN BASILICA OF SAN NAZARO, in Milan, visitors are still outnumbered by parishioners who attend the sober functions of the Ambrosian rite, ancient liturgy of the Milanese Church. On display are booklets on the lives of local saints, and among them are hagiographic biographies of an eighteenth-century woman called Maria Gaetana Agnesi. She used to live a few steps down the street, in a palazzo on Via Pantano. She was exemplary for her Christian virtue and for her charitable activity. She was not a member of a religious order but a wealthy parishioner who devoted her life and her fortune to the support of the poor and sick in Milan. A visitor might wonder whether she was the Agnesi who is cited in histories of mathematics as the author of an early textbook on calculus. The priest of the parish would answer that yes, she also wrote

\footnotetext{
* Institute for the History and Philosophy of Science and Technology, University of Toronto, Toronto, Ontario M5S 1K7, Canada.

I am grateful to the Dibner Institute for giving me the opportunity to work on this paper. Helpful comments on earlier drafts were received from Bernadette Bensaude-Vincent, Mario Biagioli, David Bloor, Ken Caneva, Marta Cavazza, I. Bernard Cohen, John Fauvel, Moti Feingold, Paula Findlen, John Henry, Pamela Long, Katharine Park, and Margaret Rossiter; from the referees for Isis; and from audiences at Harvard University (where this paper was first presented in May 2000), the Centre Koyré in Paris, and the University of Bologna.
} 


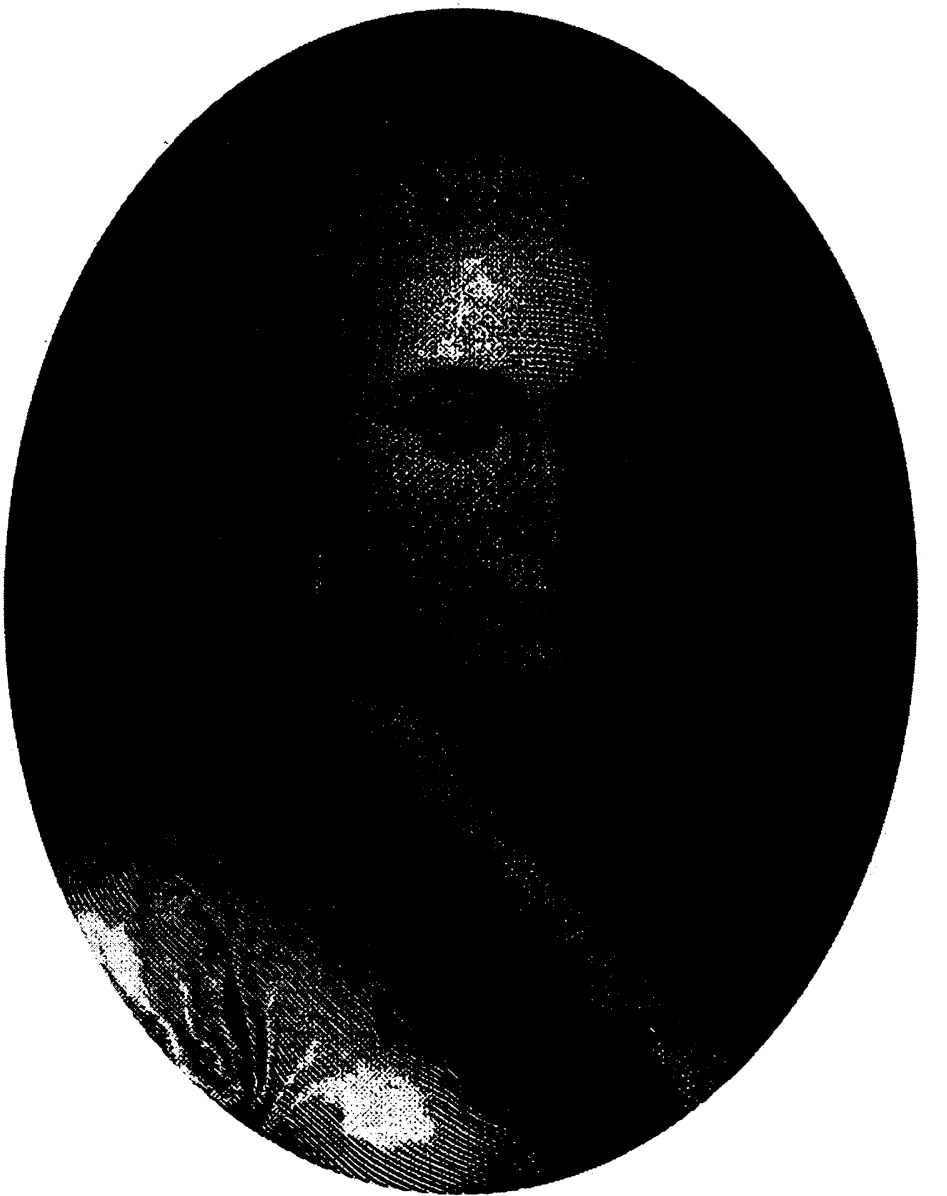

Maria Gaetana Agnesi (ca. 1748). Drawing by Maria Longhi, engraving by Ernesta Bisi. 
something about mathematics. But that is clearly not the reason why her life is on the shelf.

To connect the semiholy figure of this mysterious eighteenth-century Catholic heroine with that of Maria Gaetana Agnesi (1718-1799), the first woman to publish a mathematical work, is not a straightforward task (see Frontispiece). It is necessary to delve into the under-researched biography and work of a woman who was, by the end of the eighteenth century, both an antimodern symbol of the Catholic faith and a celebrated protagonist of the Italian Enlightenment. In 1749 she received jewels as a gift from the Empress Maria Theresa of Austria, to whom she had dedicated a book that argued for women's right of access to the "sublime sciences." At the same time, she was acting as an advisor to the archbishop of Milan on delicate theological matters. In 1799 both radical authors and Catholic conservatives mourned her death. A fundamental tension between tradition and innovation seems to pervade both her life and her work; a nineteenth-century biographer described Agnesi as a "psychological enigma." The numerous biographical notes on Agnesi say little about why she wrote her mathematics book and how it was related to the Milanese culture of her time. ${ }^{1}$

This essay offers a reconstruction of Agnesi's philosophical interests and religious faith and considers how they shaped her mathematical work. I will sketch the particular cultural and social conditions that made it possible for an eighteenth-century woman to establish herself as a legitimate scientific author. In particular, I argue that an unprecedented social space was opened for (a few) talented women in the context of the reformist Catholic tradition that culminated in the pontificate of Benedict XIV (1740-1758). This tradition, which rapidly declined in the second half of the century, found one of its strongholds in Milan. Neither more conservative traditional Catholicism nor the radical culture of the Enlightenment seems to have offered women comparable opportunities for recognition as legitimate scientific authors and members of scientific institutions. ${ }^{2}$

One important issue that needs to be reassessed is the historical significance of Agnesi's mathematical work. In 1748 Agnesi published the two volumes of Instituzioni analitiche ad uso della gioventù italiana [Analytical Institutions for the Use of Italian Youth] (see Figure 1), which presented the principles and methods of algebra, Cartesian geometry, and

\footnotetext{
${ }^{1}$ Carlo Francesco Gabba, Commemorazione di Maria Gaetana Agnesi (1899), quoted in Maria Luisa Anzoletti, Maria Gaetana Agnesi (Milan: Cogliati, 1901) (hereafter cited as Anzoletti, Agnesi), p. 340. The first biographical note on Agnesi appeared as early as 1753, in Giammaria Mazzuchelli, Gli scrittori d'Italia cioé notizie storiche, e critiche intorno alle vite, e agli scritti dei litterati italiani, 2 vols., Vol. 1 (Brescia, 1753), pp. 198201. Most of Agnesi's biographies have been written for apologetic purposes. They are invariably based on Antonio Francesco Frisi, Elogio storico di D.a Maria Gaetana Agnesi milanese (Milan, 1799) (hereafter cited as Frisi, Elogio di Agnesi [1799]), which remains the most valuable source of information. Arnaldo and Giuseppina Masotti have edited an annotated version of Frisi's biography: Frisi, Elogio di Donal Maria Gaetana Agnesi, ed. Arnaldo Masotti and Giuseppina Masotti (Milan: Pio Istituto pei Figli della Provvidenza, 1965). Important additional material on Agnesi's life and on her circle of friends and correspondents can be found in Anzoletti, Agnesi; and in Arnaldo Masotti, Maria Gaetana Agnesi (Milan: Libreria Editrice Politecnica, 1940). Among the other biographical works see Amato Amati, Onoranze centenarie a M. Gaetana Agnesi (Milan, 1899); Cornelia Benazzoli, Maria Gaetana Agnesi (Milan: Bocca, 1939); Edna Kramer, "Maria Gaetana Agnesi," in Dictionary of Scientific Biography, ed. C. C. Gillispie, 16 vols. (New York: Scribners, 1970-1984), Vol. 1, pp. 75-77; Lynn Olson, Women in Mathematics (Cambridge, Mass.: MIT Press, 1974), pp. 33-48; and Giovanna Tilche, Maria Gaetana Agnesi (Milan: Rizzoli, 1984). New archival material pertaining to Agnesi's life and to her family has recently been published in Adele Bellù, Giulio Giacometti, Anna Serralunga Bardazza, and Piero Sessa, Maria Gaetana Agnesi, ricercatrice di Gesù Cristo, 2 vols., Vol. 1: Vita e opere (Milan: NED, 1999).

${ }^{2}$ An interesting comparison can be established with the role of women in French salon culture. See, e.g., Mary Terrall, "Émilie du Châtelet and the Gendering of Science," History of Science, 1995, 33:283-310; and Dena Goodman, The Republic of Letters: A Cultural History of the French Enlightenment (Ithaca, N.Y.: Cornell Univ. Press, 1994).
} 


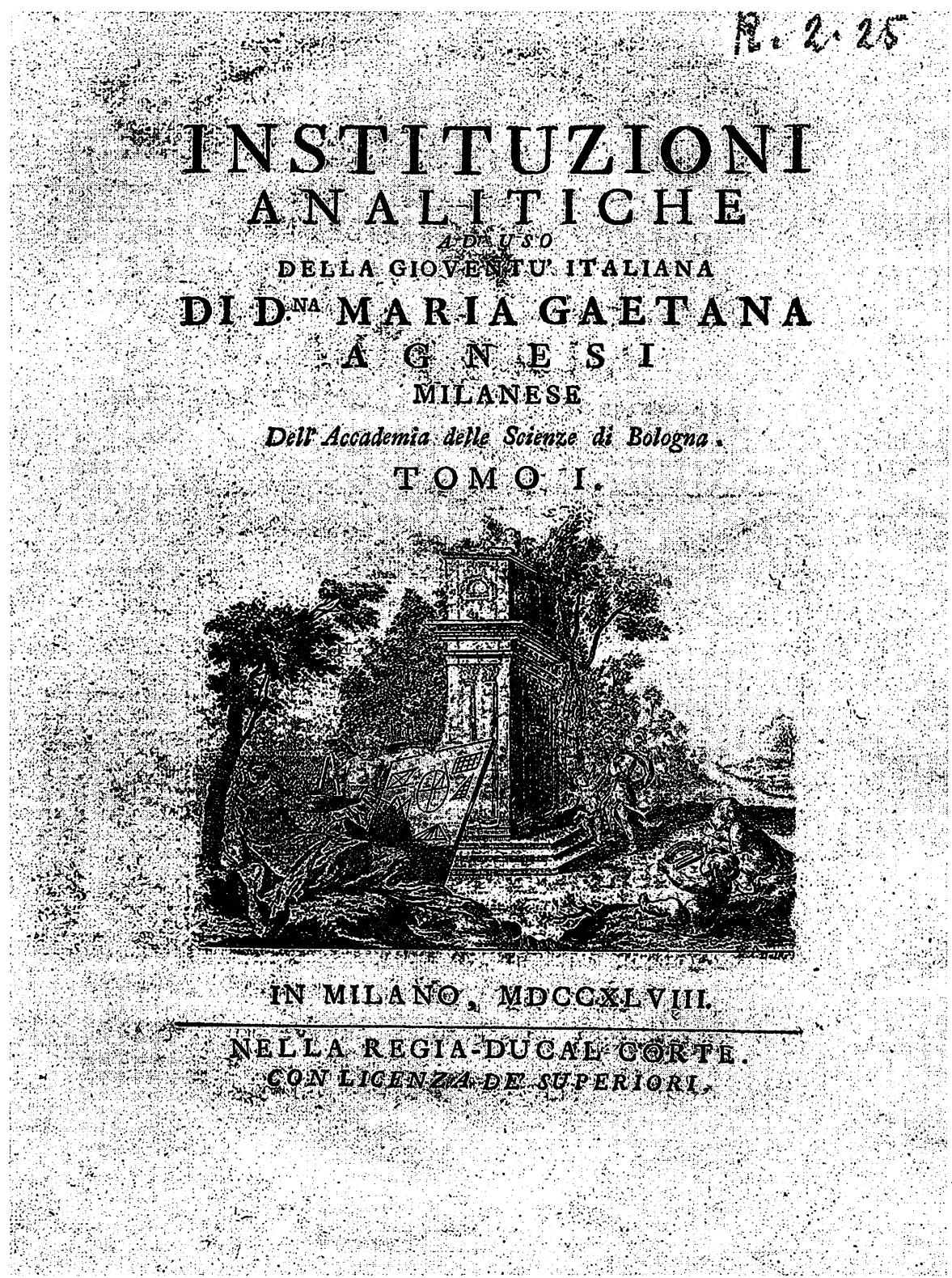

Figure 1. Maria Gaetana Agnesi, Instituzioni analitiche (Milan, 1748), Volume 1, title page.

calculus. It was among the first textbooks to offer such a complete introductory surveyand certainly the most accessible to beginners, thanks to Agnesi's use of the vernacular and her didactic method. Agnesi linked the practice of algebra for finite quantities to the techniques of differential and integral calculus in what she considered a "natural" and simple way. The textbook enjoyed remarkable success and remained a standard reference work during the second half of the eighteenth century. Instituzioni analitiche presented some peculiarities of style and content that differentiated it from comparable works of the 
same period. Clifford Truesdell has remarked on Agnesi's lack of originality, relating the unusual aspects of the book to what he holds to be her lack of competence. ${ }^{3}$ But a comparison of Agnesi's work to the textbooks of Leonhard Euler or the essays by leading Italian practitioners can be misleading if we overlook the differences in their specific purposes and in their broader cultural orientations.

In the first half of the eighteenth century many Catholic intellectuals, in Italy and abroad, were looking for a way to reform both the structure of the church and the structure of knowledge without abandoning Catholic orthodoxy. The story of Maria Gaetana Agnesi takes us to the core of this ambitious cultural project.

\section{THE METAMORPHOSIS OF TRADITION}

The Milanese Pietro Verri (1728-1797), a radical author and a protagonist of the Italian Enlightenment, referred to the philosophical and scientific culture of Agnesi's youth as "a motley of Aristotelian opinions and Cartesian imagination." ${ }^{4}$ In fact, although firmly rooted in the traditional Catholic worldview, Lombard culture was undergoing remarkable transformations. Its form was based on the Jesuit ratio studiorum, which was still dominant in Lombard institutions of higher education in the absence of a local Galilean tradition. Notable mathematicians worked within this framework, among them Girolamo Saccheri (1667-1733) and Rudjer Boscovich (1711-1787), both professors of mathematics at the University of Pavia. From the early eighteenth century on, however, this cultural system faced new problems and challenges, mainly related to the development of the experimental sciences and the connection between experimental scientific practices and rationalist philosophies. Agnesi and other reformist Catholic authors elaborated sophisticated responses to the religious, cultural, and social challenges of the century.

Among Agnesi's tutors and correspondents were authoritative ecclesiastics with an interest in modern scientific practices, like the Somaschan priest Francesco Manara, professor of logic and experimental physics at the University of Pavia, and the Olivetan monk Ramiro Rampinelli, who taught at religious colleges in Bologna and Milan and from 1747 lectured at Pavia. Also close to Agnesi was the Celestine monk Serafino Brancone, later professor at the University of Naples and a bishop in that kingdom. Among the few lay figures of this Milanese circle was Agnesi's teacher and friend Count Carlo Belloni, from Pavia, an enthusiastic supporter of the new experimental sciences. Agnesi was tutored in rhetoric and Greek by abbé Girolamo Tagliazucchi (1674-1751), the author of an influential pedagogical treatise that was reprinted well into the nineteenth century. ${ }^{5}$

\footnotetext{
${ }^{3}$ Maria Gaetana Agnesi, Instituzioni analitiche ad uso della gioventù italiana, 2 vols. (Milan, 1748); and Clifford Truesdell, "Maria Gaetana Agnesi," Archive for the History of Exact Sciences, 1989, 40:113-142. On continuing use of the textbook in the eighteenth century see Luigi Pepe, "Sulla trattatistica del calcolo infinitesimale in Italia nel secolo XVIII," in La storia delle matematiche in Italia, Atti del convegno (Cagliari: Univ. Cagliari, 1983), pp. 145-227, on p. 161. In 1749 Jean Jacques d'Ortus de Mairan (1678-1771) and Etienne Mignot de Montigny (1714-1782) read and commented extremely favorably on Agnesi's book on behalf of the Académie Royale des Sciences. Their report is reproduced in Frisi, Elogio di Agnesi, ed. Masotti and Masotti (cit. n. 1), pp. 101-107. The second volume of Agnesi's textbook was translated into French as Traités élémentaires de calcul différentiel et de calcul intégral (Paris, 1775) and reviewed in the Journal des Sçavans, Feb. 1776, p. 125. It was translated into English as Analytical Institutions (London, 1801); the translation was by John Colson (1680-1760), Lucasian Professor of Mathematics at the University of Cambridge, and was edited by John Hellins.

${ }^{4}$ Pietro Verri, Memorie appartenenti alla vita ed agli studj del signor Don Paolo Frisi (1787), quoted in Anzoletti, Agnesi, p. 152. (Here and elsewhere, translations into English are my own unless otherwise indicated.)

${ }^{5}$ Girolamo Tagliazucchi, Della maniera d'ammaestrare la gioventù nelle umane lettere (Turin, 1882). Agnesi
} 
An interest in didactic issues and in the pedagogy of the modern sciences was a notable feature of the reformist movement of the early and mid-eighteenth century known variously as the "katholische Aufklärung," "Lumières catholiques," and "cattolicesimo illuminato." In this essay I refer to this multifaceted cultural and religious movement as the "Catholic Enlightenment."' Enlightened Catholics argued, among other things, for the necessity to reform teaching so as to include materials and methods from the modern sciences, but without altering the general religious framework. In Lombardy, the results of this approach were remarkable: Rampinelli and Agnesi were among the first to support the teaching of modern analysis, while Manara and Belloni were the staunchest defenders of experimental methods in physics. In 1742 Manara addressed the faculty and students of the University of Pavia with a speech that was a manifesto of the enlightened Catholic perspective on scientific teaching. He distanced himself from scholastic teaching, arguing that the science of nature is strictly limited to phenomena, as distinguished from essences, and that any $a$ priori approach should be rejected in favor of a purely descriptive one, inspired by the Newtonian tradition and by the Dutch experimentalists Willem Jacob s'Gravesande and Petrus van Musschenbroeck. At the same time, he insisted, the realm of metaphysical truths and religious dogmas remained untouched by the new experimentalism. Conflict between the "truths" discovered in the different spheres of being (metaphysics, mathematics, the empirical world) was to be prevented by limiting the mathematician's legitimate work to contemplation of the properties of abstract objects and by introducing a cautious skepticism and a tolerant eclecticism with regard to the study of the features of empirical reality. Well-known philosophical textbooks in use during the first half of the century featured a similar moderate approach, among them Edmond Purchot's Institutiones philosophicae, on which Agnesi's cursus studiorum in philosophy was based. ${ }^{7}$ These works were characterized by a teleological ontology derived mainly from Descartes and Malebranche, an apologetic reading of Newton's natural philosophy, and a skeptical attitude toward the possibility of certain knowledge about any empirical state of affairs.

Arithmetic and geometry enjoyed a well-defined epistemological and methodological position in the traditional curriculum. The reformers' task was to introduce the modern concepts and techniques of analysis without altering the general features of the field and to preserve the integrity of traditional disciplinary boundaries. Unlike our contemporary

dedicated her philosophical theses to Belloni: Maria Gaetana Agnesi, Propositiones philosophicae, quas crebris disputationibus domi habitis coram clarissimus viris explicabat extempore, et ab objectis vindicabat Maria Cajetana de Agnesiis mediolanensis (Milan, 1738). The dedication reads: "viro nobilissimo, et litteratissimo Carolo Bellono Comiti montis Acuti Beccariae, J.C.C., et Decurioni Regiae Civitatis Papiae"-from which we know of his role in the administration of Pavia. Belloni was also a member of the local "colony" of the Arcadia Society; see Carlo Vianello, La giovinezza di Parini, Verri, e Beccaria (Milan: Baldini \& Castoldi, 1933), p. 49. A few letters and manuscripts by Belloni are in the Biblioteca Ambrosiana, Milan, 0.199-201.Sup.

${ }^{6}$ There is a rich literature on the Catholic Enlightenment, following the pioneering studies of Émile Appolis, Entre jansénistes et zelanti: Le "tiers parti" catholique au XVIII siècle (Paris: Picard, 1960); Bernard Plongeron, "Recherches sur l'Aufklärung catholique en Europe occidentale, 1770-1830," Revue d'Histoire Moderne et Contemporaine, 1969, 16:555-605; and Louis J. Rogier, "L'Aufklärung cattolica," Nuova Storia della Chiesa, 1971, 4:151-174. For the Italian context see Mario Rosa, Riformatori e ribelli nel Settecento religioso italiano (Bari: Dedalo, 1969); and Rosa, ed., Cattolicesimo e Lumi nel Settecento italiano (Rome: Herder, 1981). For further bibliographical references see Claudio Manzoni, Il "cattolicesimo illuminato" in Italia: Tra cartesianismo, leibnizismo e newtonismo-lockismo nel primo Settecento (1700-1750): Note di ricerca sulla recente storiografia (Trieste: LINT, 1992).

${ }^{7}$ Edmond Purchot, Institutiones philosophicae ad faciliorem veterum ac recentiorum philosophorum lectionem comparatae, 4 vols. (Lyon, 1711); this text was reprinted repeatedly in Italy in the 1720s and 1730s. The content is structured as follows: logic and metaphysics (Vol. 1), geometry and "physica generalis" (Vol. 2), "physica specialis" (Vol. 3), ethics (Vol. 4). See also the Institutiones philosophicae ac mathematicae (Florence, 1721, 1737), by the Piarist Edoardo Corsini. 
distinction between pure mathematics and applied mathematics, the distinction between mathematics and philosophy was based on a clear-cut divide: mathematical reasoning followed quantitative-demonstrative methods, whereas philosophical reasoning was based on logical-disputative methods. ${ }^{8}$ Rampinelli, Agnesi's mathematics tutor, is a significant case in point. Related to the leading practitioners of calculus in Bologna and the Veneto, he was around 1750 the most remarkable mathematician active in Lombardy. Devoted to the diffusion of the analytic methods and of infinitesimal calculus through his teaching, he neatly separated the technical aspects of mathematical practice from any potentially "subversive" philosophical ideologies that could be associated with it. Rampinelli's caution in philosophical matters was renowned; his biographer noted his "religious" abstention from the heated debates that divided the literati, so that no one ever knew with which party he sided. ${ }^{9}$

The activity of these devout natural philosophers and mathematicians should be understood in the context of a broader movement for the institutional and cultural reform of Catholicism, which found one of its foremost leaders in the erudite historian Antonio Ludovico Muratori (1672-1750). Muratori was very influential in early eighteenth-century Milan, and his books were in Agnesi's family library. His historiographical method, anticurial campaigns, and religious reformism were to be influential in Italy, Spain, Portugal, and the German-speaking countries. Between 1740 and 1750, thanks to the support of Benedict XIV, the Muratorian influence reached its apogee, shaping the choices of European Catholicism. Muratori, who was primarily concerned with the issue of the boundaries between freedom of thought and religious faith, defended a "reasonable" and antibaroque Catholicism, often in contrast to Jesuit positions. At the same time, he tried to distance himself from the more radical Jansenist and rigorist views current at the same time (thus his has been described as a "third way" in eighteenth-century Catholicism). Muratori argued for the creation of new schools and missions devoted to teaching Christian doctrine to the people and for a more sober liturgy in which Latin would be replaced by the vernacular. The philosophical background of his work was essentially Cartesian, from its general methodology to its mechanist conception of nature, though this was a Cartesianism filtered through Malebranche's apologetic interpretation. In 1735 Muratori published a work addressed to young people that criticized Locke's utilitarianism and hedonism by referring to the "original" moral principles found in the New Testament gospels. ${ }^{10}$

\footnotetext{
${ }^{8}$ The traditional term for these studies was "mixed mathematics," as in them mathematical considerations were mixed up with considerations about contingent matters of fact. As a consequence, the issues treated by mixed mathematics could raise a range of important philosophical problems. Because of its connections to natural philosophy and morality, in the traditional curriculum "experimental physics" (or "particular physics") was separated from the teaching of mathematical disciplines and listed among the philosophical courses. See Ugo Baldini, "L'insegnamento fisico-matematico a Pavia alle soglie dell'età teresiana," in Economia, istituzioni, cultura in Lombardia nell' età di Maria Teresa, ed. Aldo de Maddalena, Ettore Rotelli, and Gennaro Barbarisi, 3 vols., Vol. 3: Istituzioni e società (Bologna: Mulino, 1982), pp. 863-886.

${ }^{9}$ Francesco Turriceno, "De vita Ramiri Rampinelli Epistola," in Ramiro Rampinelli, Lectiones opticae (Brescia, 1760), pp. xi-xxxi, on p. xxx. On Rampinelli see also Paolo Guerrini, "Il maestro di Maria Gaetana Agnesi," Scuola Cattolica, 1919, 17:250-256; and Carlo Succi, "Un matematico bresciano: Ramiro Rampinelli monaco olivetano (1697-1759)," Commentari Ateneo di Brescia, 1992 (suppl.).

${ }^{10}$ The manifesto of the Muratorian position was Lamindo Pritanio [L. A. Muratori], De ingeniorum moderatione in religionis negotio, ubi quae jura, quae frena futura sint homini christiano in inquirenda et tradenda veritate, ostenditur, et Sanctus Augustinus vindicatur a multiplici censura Joannis Phereponi (Paris, 1714). See also Muratori, Della carità cristiana in quanto essa è amore del prossimo (Modena, 1723); Muratori, Della regolata divozione de' cristiani (Venice, 1723); Muratori, La filosofia morale esposta e proposta a $i$ giovani (Venice, 1735); and Muratori, Delle forze dell'intendimento umano, osia il pirronismo confutato (Venice, 1735). On Muratorian reformism see Franco Venturi, Settecento riformatore, Vol. 1: De Muratori a Beccaria (Turin:
} 
Muratorian reformism informed the activity of Agnesi's circle as well as that of other elite intellectual groups in northern Italy. Consider the cultural milieu of another woman philosopher, Cristina Roccati (1732-1797) from Rovigo, in the Veneto. One finds the same apologetic reading of Newtonian natural philosophy, the same references to Cartesianism, to Malebranche, to Muratori's morals and didactics, and to the reformism of Pope Benedict XIV. Among the few books that Roccati kept for herself after selling the family library in 1758 was Agnesi's Instituzioni analitiche. ${ }^{11}$

Enlightened Catholicism found a particularly favorable terrain in Bologna, where Archbishop Prospero Lambertini (the future Benedict XIV) had been supporting the modernization of university teaching and the opening to "ultramontane" (i.e., British and French) culture since the early 1730 s. Equally relevant was the role played by Muratorian reformism in the Lombard context. Since the early years of the century ecclesiastic institutions had been strengthened in Milan, and a renewed religious fervor seemed to penetrate certain sectors of Milanese society. The pastoral model of Archbishop Carlo Borromeo, the attachment to the tenets of the Counter Reformation (as defined by the Council of Trent), and the campaign for religious and moral education were the pillars of this renewed ecclesiastical life. Increasing attention was paid to the education and the moral rigor of the clergy, which became proverbial. The sober religiosity advocated by Milanese archbishops accorded relevance to both sensibility and reason; ideally, the believer was "to stay in the world without being of the world." 12 They held that the highest spiritual achievements were open to the average person, not only to those living in the quiet of the cloister. This was a moderate and "civil" devotion based on recognition of the boundless mercy of God, a positive view of the human being, and confidence in the relevance of the action of believers in civil society. The Jesuits did not oppose the reform movement, which in their perspective contrasted favorably with the stress on grace and the moral rigor of both the Protestant churches and the Jansenist clergy. The differences between the Jesuits and the reformers were clear at many levels, however, from liturgy to didactic methodology. Consider, for instance, the importance attributed to the teaching of Italian language and literature in the pedagogical manifesto of the Somaschans (1741) and their rejection of the centrality of Latin in the Jesuit curriculum. ${ }^{13}$

Most representative of the reformist tradition in Milan was the early pastoral activity of Archbishop Giuseppe Pozzobonelli (in charge from 1743 to 1783), a friend and ecclesiastical supporter of Benedict XIV and one of Agnesi's patrons. Pozzobonelli encouraged the foundation of new confraternities and new schools of catechism and attempted to

Einaud: 1998), pp. 59-186; and Mario Rosa, "L' 'età muratoriana' nell'Italia del '700," in Riformatori e ribelli (cit. n. 6), pp. 9-47. For a partial list of the books in the Agnesi library see Bellù et al., Agnesi, Vol. 1 (cit. n. 1), pp. 128-137.

${ }^{11}$ Paula Findlen, “A Forgotten Newtonian: Women and Science in the Italian Provinces," in The Sciences in Enlightened Europe, ed. William Clark, Jan Golinski, and Simon Schaffer (Chicago: Univ. Chicago Press, 1999), pp. 313-349, on p. 333. On the "third way" of Benedict XIV see Mario Rosa, "Tra Muratori, il giansenismo e i 'lumi': Profilo di Benedetto XIV," in Riformatori e ribelli, pp. 49-85.

12 Paola Vismara, "Il volto religioso di Milano nel primo Settecento," in Politica, vita religiosa, carità: Milano nel primo Settecento, ed. Marco Bona Castellotti, Edoardo Bressan, and Vismara (Milan: Jaca, 1997), pp. 129156 , esp. pp. 136-137, 144 (quotation). For a panorama of eighteenth-century Lombard religious life see Vismara, Settecento religioso in Lombardia (Milan: NED, 1994); on the reformist action of the Milanese Church see Angelo Majo, Storia della Chiesa Ambrosiana, 5 vols., Vol. 3: Dalla riforma cattolica a Gaetano Gaysruck (Milan: NED, 1985), pp. 91-129. For an introduction to the history and culture of the state of Milan in the eighteenth century see Carlo Capra, "Il Settecento," in Domenico Sella and Capra, Il Ducato di Milano dal 1535 al 1796 (Turin: Utet, 1984), pp. 153-617.

${ }^{13}$ Methodus studiorum as usus congregationis de Somascha per rei litterariae moderatores exhibita (Milan, 1741), promulgated under the supervision of Giovan Battista Riva, General of the Order of Somascha. 
regulate and moderate traditional forms of popular devotion. He promoted a form of "reasonable" spirituality grounded in the connection between devotion and charity. Great emphasis was placed on the proper role of women in this renewed religiosity and, therefore, on the education of women. Archbishop Erba Odescalchi (in charge from 1712 to 1737), for instance, had favored the creation of new institutions where the Ursulines could teach young girls. It is significant that, in the early eighteenth century, paintings of the "Education of the Virgin" - an unusual theme except in this context-were repeatedly commissioned in northern Italy, particularly by the teaching orders. An example is the altarpiece by the Ticinese painter Giuseppe Antonio Petrini created in 1744 for the Somaschan college in Lugano (see Figure 2). Like the rest of Petrini's antibaroque productions, it was an effective visual translation of the Muratorian ideals of the Catholic Enlightenment. ${ }^{14}$

How should historians interpret this religious renewal? Clearly the Catholic Church was reacting to the increasing secularization of cultural and social life by initiating a reform of its liturgy, its devotional practices, and its overall social function. The renewed missionary spirit and the opening to marginal social groups-including women-can be seen as an attempt by the church to balance the growing religious indifference of the urban patriciate, traditionally its privileged interlocutor. That this operation to ensure the simultaneous transformation and survival of traditional Catholic culture should have been particularly successful in Milan is hardly surprising. At the turn of the eighteenth century, Lombard society was less open to innovation and more linked to the forms of the ancien régime than that of the neighboring states. The landed aristocracy preserved much of its political and economic power, and its members were invariably educated in Barnabite or Jesuit colleges whose curricula were designed to preserve and transmit traditional values. Lombard academic institutions were less open to cultural innovation than their Tuscan, Venetian, Emilian, or Piedmontese counterparts. Significantly, there was no stable academy of sciences in Lombardy, and the teaching of the physical and mathematical sciences remained firmly in the hands of the religious orders until the mid-eighteenth century. The introduction of the modern sciences in Lombardy therefore took the form of a creative appropriation of experimental practices and mathematical techniques by men and women who acted within the context of traditional institutions (universities, colleges, private academies) and aimed to defend an essentially traditional structure of knowledge. Far from being an immobile background against which "Enlightenment" made its entrance on the cultural and social scene, then, early eighteenth-century traditional culture was a lively and continuously changing terrain.

\section{CHILD PRODIGIES AND THEIR USES}

Among the "new men" struggling for recognition in the rigidly structured Milanese society was the wealthy Pietro Agnesi (ca. 1690-1752), Maria Gaetana's father. Very little is known about him, although he played a crucial role in directing Maria Gaetana's education

\footnotetext{
${ }^{14}$ On "reasonable" spirituality see Vismara, "Volto religioso di Milano" (cit. n. 12), p 153; on the creation of Ursuline educational institutions see M. Knerich, "Le Orsoline di san Carlo," Diocesi di Milano-Terra Ambrosiana, 1960, 1:47-51; on Ursuline didactics see Philippe Annaert, Les colleges au feminine: Les Ursulines: Enseignment et vie consacrée aux XVIIe et XVIIIe siècles (Namur: Vie Consacrée, 1992). On the connection between Petrini and the Order of Somascha see Simonetta Coppa, "La committenza degli ordini religiosi nella Lombardia austriaca: Alcune esemplificazioni," in Politica, vita religiosa, carità, ed. Castellotti et al. (cit. n. 12), pp. 273-284. On this painting see also Edoardo Arslan, Giuseppe Antonio Petrini (Lugano: Società Ticinese di Belle Arti, 1960), pp. 58-61.
} 


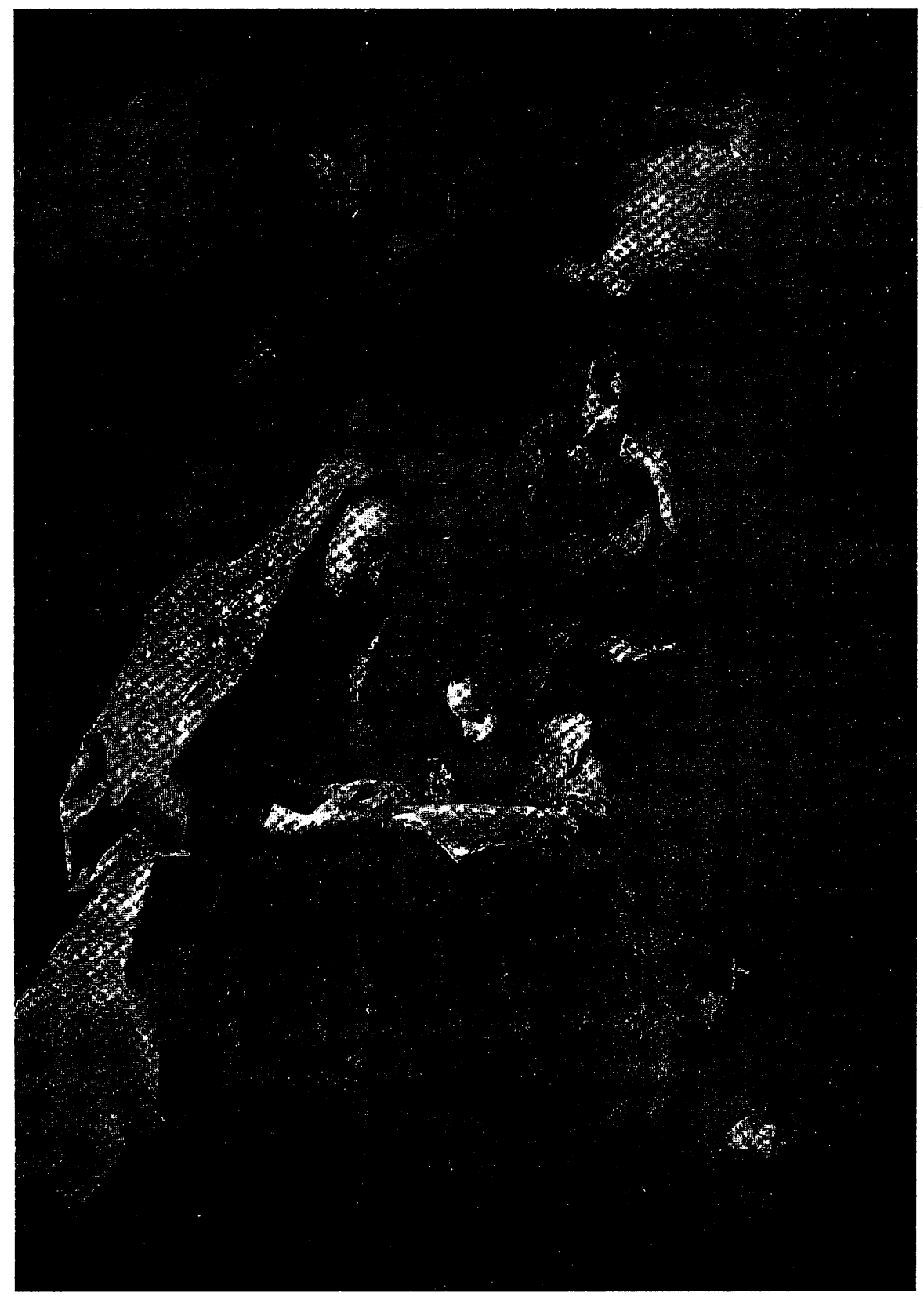

Figure 2. Giuseppe Antonio Petrini, Education of the Virgin (1744). Lugano, Chiesa di San Antonio Abate. 
and indeed her life. Reports that Pietro held a teaching position at the University of Bologna that was taken over by his daughter after his death are clearly mistaken. The Agnesi, who had settled in Milan at the beginning of the seventeenth century, had traditionally been active in the trade of silk textiles. The wills of Pietro's father and uncle suggest that they had accumulated a remarkable patrimony and that at the turn of the century the family was one of the wealthiest in that trade..$^{15}$

Pietro's administration of the family fortune was not consistent with the practices of his sober merchant ancestors. Pursuing a strategy of social enhancement intended to elevate the family from the bourgeoisie to the patriciate, he adopted the style of living proper to Milanese patrician families. ${ }^{16}$ In the end, Pietro's socioeconomic strategy proved to be disastrous, the fortunes of the Agnesi declining rapidly during the second half of the century. ${ }^{17}$

In the shorter term, however, this strategy of social enhancement explains much of Pietro's interest in literary and scientific culture, his liberal patronage of the arts, and his creation of a library for the family palazzo. It also explains the unusual attention Pietro paid to the education of his numerous sons and daughters. It was far from common, even in patrician families, to engage illustrious teachers for the education of many children, let alone many girls. On the other hand, as Paula Findlen has pointed out, in early eighteenthcentury Italy a few bourgeois families did invest their limited wealth in the education of a single son or daughter who might later find a prestigious academic position. Such was the case with the natural philosophers Laura Bassi (1711-1778) and Cristina Roccati (1732-1797). Pietro operated on a larger scale: his goal was not monetary return but, rather, a coat of arms and the title of Milanese patrician. ${ }^{18}$

\footnotetext{
${ }^{15}$ The claim that Pietro Agnesi held a teaching post in Bologna, though proved incorrect in Anzoletti, Agnesi, appears in most nineteenth- and twentieth-century biographies of Agnesi. See, e.g., Kramer, "Agnesi” (cit. n. 1), p. 75; and Olson, Women in Mathematics (cit. n. 1), p. 39. On the family's wealth see Anna Serralunga Bardazza, "Scoperta di nuove fonti," in Bellù et al., Agnesi, Vol. 1 (cit. n. 1), pp. 109-177.

${ }^{16}$ In 1740 Pietro acquired the imperial feud, or fief, of Montevecchia, in the Lombard countryside, which enabled him to use the title of "feudatory." But formal recognition of the family's new status came only after Pietro's death: in 1775, following the approval of the Heraldic Tribunal, the Agnesi coat of arms was added to the heraldic codex of Milan. See Enrico Casanova, Dizionario feudale delle provincie componenti l'antico Stato di Milano all'epoca della cessazione del sistema feudale (1796) (Bologna: Forni, 1970), pp. 66-67. Antonio Francesco Frisi (1734-1817), the author of an otherwise well-informed biography of Agnesi, dated the nobility of the family to well before the birth of Maria Gaetana. Therefore she has been defined as a "Milanese patrician" and her father described as a "noble" by some later biographers. It should be noted, however, that Frisi was close to the Agnesi family and a personal friend of Giuseppe Agnesi (1735-1820), son of Pietro and brother of Maria Gaetana. For all the valuable information that it contains, Frisi's life of Agnesi should be recognized for what it is: a eulogy of Pietro and a celebration of the family. Even after 1740 Pietro was far from entering the Milanese patriciate, a restricted group of families that had controlled the local senate for centuries. See Francesca Pino, "Patriziato e decurionato a Milano nel secolo XVIII," Società e Storia, 1979, 5:339-378.

${ }^{17}$ Pietro Agnesi was by no means the only wealthy merchant who chose to invest in land and social prestige. Giuseppe Parini opened his satirical poem on the way of life of the Lombard aristocracy by addressing precisely those who had recently abandoned trade to acquire fiefs and titles: "Whether, Young sir, thy blood celestial flow/ Most pure by long descent from noble loins,/Or purchas'd dignities the blood's defect/Make good by aid of wealth thy frugal father/Amass'd in few short years by sea or land,/Hearken to me, of pleasant Rites the Teacher." Giuseppe Parini, Il mattino (1763), $l l$. 1-6 (the opening lines of the poem). Nor was the Agnesi the only family to come to grief. In the malicious words of a later historian of the Milanese patriciate, "the families that have become great by artificial means have generally much less resistance, cohesion, and strength - and consequently a much shorter moral life - than those that became great in a natural way": Felice Calvi, II patriziato Milanese (Milan, 1875), p. 74. For a recent assessment of the changing investment strategies of Milanese elites at the turn of the eighteenth century see Stefano Agnoletto, Lo Stato di Milano al principio del Settecento: Finanza pubblica, sistema fiscale e interessi locali (Milan: Franco Angeli, 2000), pp. 315-342.

${ }^{18}$ On Bassi see Paula Findlen, "Science as a Career in Enlightenment Italy: The Strategies of Laura Bassi," Isis, 1993, 84:441-469; on Cristina Roccati see Findlen, "Forgotten Newtonian" (cit. n. 11). For similar inter-
} 
Pietro also followed the example of ancient patrician families in opening his palazzo on Via Pantano to salon culture. Magistrates, senators, Arcadian literati, university professors, ecclesiastics, and foreign travelers came together regularly in the domestic accademie at the Palazzo Agnesi, where they declaimed poetry and discussed scientific issues while sampling chocolate (in the winter) and sorbets (in the summer). As two of his daughters showed a particular inclination for music and foreign languages, Pietro made sure that they had the best tutors available. Maria Gaetana soon began amusing her father's hosts with her wit and her fluent French. A sonnet published in 1723 eulogized the talented fiveyear-old. In the years that followed Pietro hired for his daughter prestigious tutors in Latin, Greek, Hebrew, and German. She and her sister Maria Teresa (1720-1795) often "performed" together at the palazzo: Maria Gaetana conversed with guests in different languages, and Maria Teresa played the harpsichord. ${ }^{19}$

In the summer of 1727 a particularly notable gathering was held in the garden of the Palazzo Agnesi. Maria Gaetana, aged nine, declaimed from memory a long Latin oration, probably composed by her tutor, against the rooted prejudice that women should not be allowed to study and practice the fine arts and the sciences. Among those in attendance were senators and magistrates. The child's remarkable performance caused much enthusiasm among the guests, who decided to publish in her honor a pamphlet that included the oration and a series of poetic compositions in various meters and languages. ${ }^{20}$ The latter are, in general, as nebulous and pompous as most of the Arcadian poetry of the time; in contrast, the oration stands out as a clear and effective defense of the right of women to the pursuit of any kind of knowledge.

The topic was a fashionable one. The right of women to study had been famously defended by, among others, Gilles Ménage (1613-1692) in his Historia mulierum philosopharum [History of the Women Philosophers] (1690). In 1723 Antonio Vallisnieri (1661-1730), a professor at the University of Padua and a frequenter of the Milanese salons, had proposed the question ("Whether women should be admitted to the study of the noble sciences and the fine arts") as a theme for discussion at the meetings of the Academy of the Ricovrati. In 1729 a publication collected various contributions on the topic, including the oration recited by Agnesi, from all over the Italian peninsula. ${ }^{21}$ While

pretations of the "staging" of Maria Gaetana and for a broader perspective on the phenomenon of eighteenthcentury female "prodigies" see Andreas Kleinert, "Maria Gaetana Agnesi und Laura Bassi: Zwei italienische gelehrte Frauen im 18. Jahrhundert," in Frauen in den exakten Naturwissenschaften, ed. Willi Schmidt and Christoph J. Scriba (Stuttgart: Steiner, 1990), pp. 71-85; Ulrike Klens, Mathematikerinnen im 18. Jahrhundert: Maria Gaetana Agnesi, Gabrielle-Emilie Du Châtelet, Sophie Germain (Pfaffenweiler: Centaurus, 1994), pp. 11-72; and Beate Ceranski, "Und sie fürchtet sich vor niemandem": Die Physikerin Laura Bassi, 1711-1778 (Frankfurt: Campus, 1996), pp. 27-31.

${ }^{19}$ [Anonymous], Alla nobile fanciulla D. Maria Gaetana Agnesi, Milanese, che nell' età di anni cinque parla mirabilmente il francese (Milan, 1723); note that Maria Gaetana is described as "noble" in the title. On Maria Teresa Agnesi see Anzoletti, Agnesi, pp. 195-202. Among her compositions were II ristoro d'Arcadia (1747) and Ciro in Armenio (1753). In 1771, on the occasion of the engagement of the Archduke Ferdinand of Austria to Beatrice d'Este, her melodrama Insubria consolata was presented along with Ascanio in Alba, a piece by the young Wolfgang Amadeus Mozart.

${ }^{20}$ For comments on the Latin oration see Anzoletti, Agnesi, pp. 86-109. The piece was probably written in Italian by abbé Niccolò Gemelli as an exercise for his pupil to translate and memorize. The full title of the pamphlet published in Agnesi's honor is Oratio, quâ ostenditur: Artium liberalium studia à femineo sexu neutiquam abhorrere habita a Maria de Agnesi's Rethoricae operam dante anno aetatis suae nono nondum exacto, die 18 Augusti 1727 (Milan, 1727); the oration recited by Agnesi is on pp. 5-18. On its pedagogical contents see Giovan Battista Gerini, Gli scrittori pedagogici italiani del secolo decimottavo (Turin: Paravia, 1901), pp. 85-88.

${ }^{21}$ Aegidio Menagio [Gilles Ménage], Historia mulierum philosopharum (Lyon, 1690), trans. into English as The History of Women Philosophers (Lanham, Md.: Univ. Press America, 1984); and Giovanni Antonio Volpi, 
some of the contributors supported the cause of women and invited them to challenge the intellectual primacy of men, others warned that social disruption, particularly in the structure of the family, would follow from their pursuit of serious study (a point explicitly rejected in Agnesi's oration). By 1730 the fame of Maria Gaetana "de Agnesis" as a gifted polyglot was well established in Milanese salon culture and beyond. But Pietro and his entourage had more ambitious plans for the little girl.

\section{AGNESI'S PHILOSOPHICAL STUDIES}

During the 1730s, while her sister became a well-known harpsichordist and composer, Maria Gaetana debated topics in natural philosophy and mathematics in a series of disputes with her father's guests. Manuscript material held at the Biblioteca Ambrosiana tells us about Agnesi's cursus studiorum in those years. We find lists of Latin terms and their Greek and Hebrew translations; a Latin pamphlet on mythology and its Greek translation; and a Latin text on the life of Alexander the Great translated into Italian, French, German, and Greek. There are no traces of grammars or lists of rules, which suggests that the didactic method was based on practical exercises and the direct reading of classical authors. As for the contents of this teaching, the Latin pamphlet summarizes the doctrine of the "prisca theologia"-essentially, the belief that an ancient and esoteric wisdom predated and informed much of Western culture. This was a resource that could be effectively employed to defend the primacy of religious over natural knowledge. ${ }^{22}$ Also among Agnesi's manuscripts (not everything is in her handwriting) are an outline of a course of physics and an essay on ethics. The first is divided in two branches, "general physics" and "particular physics," according to the traditional Jesuit model. The second mounted a vigorous attack against any attempt to ground morals on a sensationalistic base. Its author was the Theatine Michele Casati, with whom-judging from their letters-Agnesi had a remarkable familiarity. Casati, later a university professor in Turin and a bishop, would publish in 1765 what proved to be one of the most influential catechisms of the Catholic Church. In his manuscript for Agnesi he offered a teleological description of the system of the universe, the complexity and variety of which, he insisted, could only have originated from "a single and wisest cause," not by "mere chance." A clear demarcation was established between the different levels of reality, from brute matter to animals to the human soul, which is described as an incorporeal, spiritual substance "cognitionis capace." Allegedly directed against Epicurus, such antimaterialist and antihedonist arguments were in fact a response to what was perceived by the Catholic intelligentsia as Spinozean and Lockean attacks against the dichotomy of spirit and matter and their possible materialist implications. Following Augustine, Casati identified the "summus bonus" as the contemplation of eternal truths. ${ }^{23}$

ed., Discorsi accademici di varj autori viventi intorno agli studj delle donne la maggior parte recitati nell' Accademia de' Ricovrati di Padova (Padua, 1729), pp. 89-105 (oration recited by Agnesi).

${ }^{22}$ Biblioteca Ambrosiana, O.181-182.Sup (lists of Latin terms and translations), O.183.Sup (pamphlet on mythology and translation), O.184.Sup (Quintus Curtius Rufus, De rebus gestis Alexandri Magni, cum supplementis Freinschemii [Strasbourg, 1639]; Agnesi's manuscript text is from the supplement by Johann Freinsheim [1608-1660]). On the doctrines of the "prisca theologia" and the "philosophia perennis" see Charles Schmitt, "Perennial Philosophy: From Agostino Steuco to Leibniz," Journal of the History of Ideas, 1966, 27:505-532; Maria Muccillo, Platonismo, ermetismo e prisca theologia: Ricerche di storiografia filosofica rinascimentale (Florence: Olschki, 1996); and Wilhelm Schmidt-Biggeman, Philosophia Perennis: Historische Umrisse Abendlandischer Spiritualität in Antike, Mittelalter und Früher Neuzeit (Frankfurt: Suhrkamp, 1998).

${ }^{23}$ For the physics course see Biblioteca Ambrosiana, O.185-195.Sup; it includes a course of philosophy based 
In 1738, at the age of twenty, Agnesi completed her studies by publishing a list of philosophical theses, most of which she had defended in the disputes held at her father's palazzo. ${ }^{24}$ The book was in Latin, the language in which the disputes were conducted unless Agnesi chose to speak a modern language in order to please foreign visitors. The 191 theses are presented in the traditional Jesuit order: logic, ontology, pneumatology (which included the science of God, of the angels, and of the human mind, according to the principles of natural reason), general physics, and particular physics.

The prologue reiterates the doctrine of pre-Greek religious wisdom and asserts the fitness of women to study the fine arts and the sciences. When it comes to the nature of human knowledge, "evidence," defined in the Cartesian terms of "clarity and distinction," is taken as the supreme criterion for the truth of an idea. Where evidence is lacking and there is no clear statement based on the supreme authority of the scriptures, we are in the realm of "opinion." The knowledge attainable in this circumstance can only be "probable" and "similar to the truth" ("verisimilis"). ${ }^{25}$ This is the case with philosophical knowledge, which included natural philosophy and was grounded on the rules of Aristotelian logic and on disputative methods. Only in the realm of mathematics can true knowledge be derived with certainty from what is already known. In the section on pneumatology, which treats the relation between soul and body, Agnesi professed to find the doctrine of occasionalism, elaborated by the French Oratorian Nicolas Malebranche (1638-1715), as the most reasonable and as best reconciling reason with faith.

Agnesi's appreciation for the Malebranchian synthesis also emerges in her treatment of the acquisition of knowledge, which is described as an essentially passive process in which the human mind does not "act" but only "perceives." The very possibility of cognition is defined in terms of a voluntaristic doctrine of God-as-mediator (God lets his creatures know through "illumination") that is clearly derived from Malebranche's theory of the "vision in God." The doctrine of innate ideas is rejected as absurd, as is the belief that all knowledge comes from sensation (a doctrine attributed to "Lokius," John Locke). Cartesianism, again in the deeply apologetic version of Malebranche, provided the framework of Agnesi's "general physics." She also referred frequently to Newton's natural philosophy, which is defined as "pulcherrima et simplicissima theoria." Agnesi applauded the discovery of the laws of motion and illustrated some of their applications in ballistics, hydrostatics, and geostatics. "Newton's system" is also praised for its treatment of the natural history of celestial bodies and the nature of light and colors (an issue recently discussed in Francesco Algarotti's Il newtonianesimo per le dame). ${ }^{26}$

Two points that would be crucial in Agnesi's later mathematical work emerged from these philosophical propositions. First, like Malebranche, Agnesi freighted scientific investigation with a fundamental apologetic aim. Second, she granted a privileged position to mathematics: the term "scientia" is employed exclusively for geometry and arithmetic. Indeed, while she presents every kind of empirical knowledge as essentially fallible and open to debate, she insists that in mathematics (ultimately, geometry) one can discover

on Purchot, Institutiones philosophicae (cit. n. 8). Casati's essay is in Biblioteca Ambrosiana, O.197.Sup; see esp. fols. $2 \mathrm{r}$ (cause rather than chance), $8 \mathrm{r}$ ("in verus contemplatione, sive in sapientia"). For the catechism see Michele Casati, Compendio della dottrina cristiana (Mondovì, 1765). On this catechism and its reformist features see Pietro Stella, “Alle fonti del catechismo di San Pio X: Il catechismo di Mons. Casati," Salesianum, 1961, 23:43-66.

${ }^{24}$ Agnesi, Propositiones philosophicae (cit. n. 5).

${ }^{25}$ Ibid., p. 9.

${ }^{26} \mathrm{Ibid}$., p. 81; and Francesco Algarotti, Il newtonianesimo per le dame, ovvero dialoghi sopra la luce e i colori (Naples [actually Milan], 1737). 
and contemplate truths that are derived with absolute certainty ("certissime"). Such intellectual contemplation is defined-in accord with the tenets of Casati's essay on ethicsas the greatest earthly joy available to mankind ("quo nihil jucundius esse potest"). ${ }^{27}$

\section{THE TURN TO RELIGION AND MATHEMATICS}

By the time Agnesi's Propositiones philosophicae went to press in 1738, Milanese salon culture had entered a period of stagnation that would last for nearly two decades. As we have seen, this culture relied essentially on a few families and on small and ephemeral private academies. From 1734, when Lombardy became involved in the war of the Polish succession, and throughout the war over the Austrian succession (1740-1748), many salons and academies interrupted their scientific activities. The political struggle between factions of the local aristocracy also contributed to the crisis of the Milanese Catholic Enlightenment project.

Yet in 1739 the Palazzo Agnesi was still at the center of Milanese social life, thanks to the brilliant performances of the filosofessa. Agnesi was indeed requested by her "most loving father" to attend an increasing number of soirées. One of these was particularly remarkable. The heir to the throne of Poland had been visiting Milan and was invited to attend events at the palaces of great patrician families: the Borromeo, the Simonetta, and the Pallavicini. On a December evening the prince, "followed by a number of the most qualified and erudite nobles," visited the Palazzo Agnesi. Pietro received them "with great joy"; the palace was adorned with plentiful decorations and lights. The structure of the gathering was familiar: Maria Gaetana debated the guests on topics in natural philosophy (including the explanation of the tides, for which she referred to Newton). A report of the evening appeared in the pages of the Gazzetta di Milano. ${ }^{28}$

A few months earlier, in July 1739, Charles de Brosses (1709-1777) had attended a similar meeting. Brosses had visited the salon of Countess Clelia Borromeo del Grillo (1684-1777), who loved to discuss scientific issues and was fluent in Arabic. At Carlo Belloni's invitation, he also visited the Palazzo Agnesi. There he found some thirty people from across Europe in a circle around Agnesi, who sat on a sofa awaiting questions and challenges. While sorbets and ices were being served, Agnesi disputed with Belloni on various physical matters; then Brosses was invited to raise issues of his own choosing. In his rusty Latin, the Frenchman argued with Agnesi for about an hour on topics such as the relation between soul and body, perception, the propagation of light, and the nature of colors. Among others things, Brosses noted that Agnesi was "strongly attached to the philosophy of Newton." Though he described Agnesi as "something more stupendous than the cathedral of Milan," Brosses's enthusiastic letter ended on a note of worry: apparently she had expressed the wish to enter the cloister and take the blue habit of the Augustinian nuns. Brosses saw no reason for that; as he wrote, "She is very rich." But in fact it was after the magnificent soirées of 1739 that Agnesi explicitly expressed the desire to abandon her life in society for the quiet of the cloister. Frisi effectively describes Pietro's reaction to this request: "It was as if he had been struck by lightning." Pietro "did not dissimulate

\footnotetext{
${ }^{27}$ Agnesi, Propositiones philosophicae, pp. 19 ("Universa natura clamat deum existere"), 4. On the contents of the Propositiones philosophicae see also Klens, Mathematikerinnen im 18. Jahrhundert (cit. n. 18), pp. 136176.

${ }^{28}$ Gazzetta di Milano, 1739, no. 48, rpt. in Anzoletti, Agnesi, pp. 190-192.
} 
his sorrow at the idea of being abandoned by such a dear daughter, who was, more than the others, the delight of his life."29

That Agnesi was suffering from the exceptional circumstances of her life had already been signaled by a "strange disease" that struck her between 1730 and 1732, at the climax of her career as a child prodigy. In this period, marked by intense study and by the death of her mother, Agnesi frequently fell victim to violent nervous attacks during which she had to be immobilized to prevent her from hurting herself. Frisi's description suggests epileptic attacks; but there was also a report of an episode that resembled a suicide attempt. In 1739, during another period of repeated public performances, Agnesi expressed her desire to abandon the life her father had been imposing on her. Frisi refers to long discussions and negotiations between father and daughter. Eventually, Agnesi declared herself convinced that "God had destined her to live in the world" and to assist and relieve "suffering humanity." ${ }^{30}$ She agreed to maintain her lay status, but only on certain conditions that would make her life an unusually private one. Agnesi asked to be granted the freedom to dress simply; to frequent the church of San Nazaro at will; and to abandon balls, the theater, and other worldly amusements. She also asked to be allowed to volunteer at the Ospedale Maggiore in Milan, taking care of poor and infirm women. Occasionally, to please her father, she would still participate in the soirées at the palazzo. But her glittering public career was at an end.

During the same period, we find Agnesi turning increasingly to mathematics, "the only province of the literary world where peace reigns." She decided to abandon the study of natural philosophy and to concentrate on algebra and geometry "in order to contemplate the truths that the last one contains, . . . by which she said she felt intellectually completely satisfied." 31

\section{AGNESI'S RELIGIOSITY}

According to her first spiritual director, the Theatine priest Giuseppe Reina, Agnesi had manifested a distinctive inclination to spiritual meditation since her early years. In 1725 Reina had provided Agnesi, then seven, with a text in the mystical tradition of the Imitatio Christi, which contained a set of ascetic rules to discipline the spiritual life of the believer. ${ }^{32}$ Agnesi's spiritual practice became more intense after 1739, in parallel to her retirement from public life and her more focused study of mathematics.

By the mid 1740s Agnesi was also deepening her theological knowledge. At that time she attended some meetings of the Accademia dei Trasformati, a literary society hosted at

\footnotetext{
${ }^{29}$ Charles de Brosses, Lettres familiars sur l'Italie, 2 vols., Vol. 1 (Paris: Firmin-Didot, 1931), pp. 117-119; and Frisi, Elogio di Agnesi (1799), p. 36. Brosses remarked repeatedly on the presence of learned women in Milan. For instance, he found it "peculiar" that a woman could work on Latin texts in the Biblioteca Ambrosiana along with other scholars. The woman he saw was Francesca Manzoni (1710-1743), another enfant prodige, author of sacred tragedies, and "Poetessa dell'Imperatrice." See Brosses, Lettres familiars sur l'Italie, Vol. 1, p. 99.

${ }^{30}$ On the nervous attacks see Frisi, Elogio di Agnesi (1799), pp. 27-28; and Anzoletti, Agnesi, p. 124. For her agreement to stay "in the world" see Frisi, Elogio di Agnesi (1799), p. 36.

${ }^{31}$ The words about peace come from Benvenuto Robbio, Count of San Raffaele (1735-1794), who dedicated to Agnesi his (anonymous) book on the scientific education of women. See [Benvenuto Robbio], Disgrazie di Donna Urania, ovvero degli studj femminili (Parma, 1793), pp. 127-128. On the decision to focus on mathematics see Frisi, Elogio di Agnesi (1799), p. 37.

${ }^{32}$ Andrea Avellino, Avvertimenti necessari (Naples, 1617). The rules had originally been established to improve the spiritual life of the nuns of a Neapolitan monastery. Frisi referred to a Milanese edition of 1725, edited by Reina himself.
} 
the palazzo of Count Giuseppe Imbonati (1688-1768) that included the most prominent figures in Milanese culture. There Agnesi met the newly appointed archbishop of Milan, Cardinal Giuseppe Pozzobonelli. Clearly, the archbishop considered her particularly well informed in matters of theology, for he asked her to read and comment on a recently published book that had raised a heated debate, ending up on the Index. The book, entitled Politica, diritto e religione per ben pensare, e scegliere il vero del falso [Politics, Law, and Religion in Order to Reason Correctly, and to Distinguish Truth from Falsehood], had been published in Milan in 1742 by Marquis Giuseppe Gorini Corio, a noteworthy exponent of sensationalist and hedonist doctrines. According to Rome, Corio was too keen on Protestant and Jansenist arguments. Furthermore, his theological claims had crucial political implications that ran counter to the interests of Milanese ecclesiastical and political authorities. Throughout the book Corio expressed jurisdictionalist views, arguing for a clearer distinction between the state, the figure of the sovereign, and the church. ${ }^{33}$

Agnesi wrote in her notes for the archbishop that although Corio treated many truths of the Catholic faith effectively, "some points are made which are pernicious." She showed how Corio, in the guise of condemning false miracles and superstition, was in fact contradicting both the Fathers of the Church and the official Tridentine Catechism. Agnesi also argued that he wrongly limited the role of the Holy Virgin as the necessary mediator between Christ and mankind. Defending the cult of the relics, Agnesi noted that Corio made an unreasonable demand for "proofs": in such historical matters, she argued, "moral certainty" is all one can ask for. She drew her own authority in these judgments from the Scriptures, the Fathers of the Church, late scholastic authors such as Francisco Suárez (1548-1617), and the writings of the intransigent Cardinal Vincenzo Luigi Gotti (16641742), whose opinions she held in high regard. Interestingly, Agnesi found most worrying the fact that Corio had written his book in Italian, "the language familiar to the people," as this would make it easier for him to "perturb" the faith of those "less protected"- that is, those who lacked a sound Christian education. ${ }^{34}$

Concern for strengthening and modernizing education was a leitmotif of Agnesi's writing and spiritual activity. Like other "enlightened Catholics" who looked to improve the education of the young and the poor, she argued for a more effective integration of the

\footnotetext{
${ }^{33}$ Giuseppe Gorini Corio, Politica, diritto e religione per ben pensare, e scegliere il vero dal falso (Milan, 1742); see also Corio, L'uomo, trattato fisico e morale (Lucca, 1756), which was clearly inspired by Condillac's sensationalism and was placed on the Index in 1759. On the political and cultural issues related to the debate over Corio's book see Chiara Continisio, "Dal bene commune alla pubblica felicità: Prime riflessioni su virtù e vita civile a Milano fra Sei e Settecento," in Politica, vita religiosa, carità, ed. Castellotti et al. (cit. n. 12), pp. 157-184. On the Accademia dei Trasformati see Vianello, Parini, Verri, e Beccaria (cit. n. 5); and Guido Bezzola, "I Trasformati," in Economia, istituzioni, cultura in Lombardia nell'età di Maria Teresa, ed. Maddalena et al., Vol. 3 (cit. n. 7), pp. 355-363.

${ }^{34}$ Biblioteca Ambrosiana, O.203.Sup, fols. 1r, 2r, 9v. The manuscript has been given the title Autografo di $D$. Maria Gaetana Agnesi per eccitamento di sua Eminenza il Cardinale Giuseppe Pozzobonelli Arcivescovo di Milano sull'opera del Marchese Giuseppe Gorini Corio intitolata: "Politica, Diritto, e Religione per ben pensare e scegliere il vero dal falso." Cardinal Gotti, of the Dominican order, was one of the most authoritative apologists and controversialists of the early eighteenth century, a professor of theology at Bologna and-for a short timeGeneral Inquisitor of the Faith in Milan. Agnesi referred to his La vera chiesa di Gesú Cristo, dimostrata dai segni e dai dogmi contro i due libri di Giacomo Picenino, 3 vols. (Bologna, 1719; rpt., Milan, 1734), an attack against heretics and reformed churches in defense of the dogmas of Catholicism. She also quoted Gotti's Theologia scholastico-dogmatica juxta mentem Divi Thomae Aquinatis, 8 vols. (Bologna, 1727-1735), a defense of the value of the scholastic tradition in theology. A copy of La vera chiesa was in the library of Pietro Agnesi, together with other similar texts of modern apologetics and dogmatic theology. As for the Greek and Latin Fathers, we are told that Agnesi was allowed to consult the rich collection of Angelo Oltrocchi, director of the Seminario Maggiore from 1754 and later canon and theologian of the cathedral of Milan; see Frisi, Elogio di Agnesi (1799), p. 73.
} 
modern sciences in Catholic pedagogy and for the inclusion of women in the educational process. In fact, Agnesi habitually combined the religious and scientific components of education in her activities, from the instruction she gave her brothers and sisters to her lessons on the catechism to her philosophical and mathematical writings. In 1768 Agnesi's cathechistic activity culminated in her being nominated Prior of the Christian Doctrine [Priora della Dottrina Cristiana] in the parish of San Calimero, near the Milanese palazzo of her family. ${ }^{35}$ The position of prior, often reserved for members of the aristocracy, required the holder to direct a Compagnia Operaia Catechistica, a group of lay volunteers who taught catechism to the common people. The instruction included a preliminary program of training in literacy that had to be completed before the sacraments were imparted.

If her comments on Corio illustrate Agnesi's theological competence and ability as a controversialist, other religious manuscripts speak of her remarkable mystical vein. In the essay II cielo mistico [The Mystic Heaven] Agnesi invited the "contemplative soul" to meditate on themes from the life of Christ, to share his suffering and his virtues, and to ascend from stage to stage toward the final "mystic marriage" with Christ himself. This text can be located in a specific eighteenth-century mystical trend that exalted personal love for Christ and the ecstatic contemplation of his death and resurrection. ${ }^{36}$ According to this tradition, the acquisition of knowledge was not valuable per se; rather, it acquired relevance by being framed within a Platonic-Augustinian search for a superior wisdom. This began with the rational knowledge of God and, through the love of Christ, ascended stage by stage to its final objective, the mystical experience of the contemplation of the Holy Trinity. Thus this tradition recognized the strict relation (Agnesi used the term "conspiracy") between intellect and sensibility and defended the importance of exercising the intellect of the believer.

In concert with this tradition and with her Malebranchian inclinations, Agnesi described spiritual life as constituted by the intellectual faculty (which contemplates) and the will (which loves). The way to the mystic marriage and the Christomorphic transformation of the soul ("transforming union," in the language of spiritual theology) requires the use of both faculties. Indeed, the soul is brought to the first mystic heaven by "the gifts of intellect and Wisdom." But there is a stage when the intellect has fulfilled its function, and then it is the "burning will" that continues to guide the soul to Christ: "here, every human and angelic intellect surrenders in joy and amazement." Thus, according to Agnesi, mystic contemplation did not imply a negation of the power of the intellect but, rather, the realization of its inadequacy in taking the soul from "enlightening clarity" to "burning clarity," from cognition to love. There was cooperation rather than opposition between the two faculties: while "the human mind contemplates in marvel" the virtues of Christ, "the heart imitates them with love." ${ }^{37}$

${ }^{35}$ Anzoletti, Agnesi, p. 368. See also Eleuterio Chinea, Le scuole di dottrina cristiana nella Diocesi di Milano, 1536-1796 (Gallarate: Lazzati, 1930).

${ }^{36}$ The essay is in Archivio Borromeo, Isola Bella, ABIB.AD/LM Agnesi. Agnesi titled her manuscript $1 l$ cielo mistico, cioè contemplazione delle virtù, de' Misteri, e delle Eccellenze del Nostro Signore Gesù Cristo. The text is reproduced with a commentary in Adele Bellù, Giulio Giacometti, and Piero Sessa, Maria Gaetana Agnesi, ricercatrice di Gesù Cristo, Vol. 2: Il cielo mistico (Milan: NED, 1999). For further commentary see Giovanni Pozzi and Claudio Leonardi, Scrittrici mistiche italiane (Genoa: Marietti, 1988), pp. 610-614. Important mystical authors such as Paul of the Cross (1694-1775) and Alfonso de' Liguori (1696-1787), both saints of the Church, recommended similar forms of Christocentric devotion. Other sources for Agnesi's manuscript were the Imitatio Christi and the mystical writings of Bernard of Clairvaux (1090-1153), Bonaventura of Bagnoregio (12181274), Lorenzo Giustiniani (1381-1456), Andrea Avellino (1521-1608), and Lorenzo Scupoli (1530-1610).

${ }^{37}$ Agnesi, Cielo mistico, fols. 3r, 2r, 14v. 


\section{CALCULUS FOR THE BELIEVER}

Having considered how Agnesi came to work on mathematics and the cultural and religious context in which she wrote her calculus textbook, we can now look for a coherent explanation of its unusual form and contents. As early as 1735 Agnesi was studying Guillaume de L'Hospital's (1661-1704) posthumous analytic treatise on geometric curves under the tutelage of her friend Carlo Belloni. She wrote a commentary on L'Hospital that attempted to clarify some obscure and incomplete passages. It remained unpublished, however, as in 1740, now studying with Rampinelli, Agnesi began to think about a more ambitious work: a unitary and "naturally" structured introduction to algebra, analytic geometry, and calculus. With this in mind she contacted the Italian mathematicians who had been working on advanced topics in differential and integral calculus, in particular Count Jacopo Riccati (1676-1754)..$^{38}$

In their correspondence Agnesi does not evidence much interest in Riccati's specialist research; she was, rather, concerned with the didactic dimension of geometry and analytic methods. For earlier Italian examples she could look to only a few outdated works, such as the treatises by Guido Grandi (1703), a professor at the University of Pisa, and Rampinelli's teacher Gabriele Manfredi (1707), a professor from Bologna. Their treatises, devoted to the integration of differential equations, were the only introductions to the infinitesimal techniques printed in Italy and were several decades old. In addition, Agnesi studied the textbooks by L'Hospital (1696) and by the Oratorian priest Charles Reyneau (1708). ${ }^{39}$

Agnesi's fundamental didactic interest guided her in selecting material and in defining an appropriate style and terminology. As we have seen, she attributed great relevance to mathematics in the context of a truly Christian upbringing. The truths of geometry were exemplary in their certainty and, more specifically, assumed a crucial metaphysical relevance in the framework of a Malebranchian theory of knowledge of the sort she embraced. Her main challenge was to present the young student with the calculus, at that time the most advanced and esoteric branch of the mathematical sciences. This was still a discipline with few practitioners, and no complete textbooks were available. Agnesi noted that, although learning analysis was a "clear necessity," there were few teachers able to introduce students to its techniques; moreover, the relevant materials were spread "here and there in the books of various authors, and particularly in the Acts of Leipzig, the Memoirs of the Academy of Paris, and in many other journals." Agnesi decided to systematize these materials (ridurre a metodo), eliminating what was "superfluous" and proceeding "with that natural order, which perhaps provides the best instruction and the greatest light." She

\footnotetext{
${ }^{38}$ Agnesi studied the second edition of Guillame François de L'Hospital, Traité analytique des sections coniques et des leur usage pour la resolution des equations dans les problêmes tant déterminez qu'indéterminez (1707; Paris, 1720). Her commentary is in Biblioteca Ambrosiana, O.199-200.Sup. On calculus in Italy in the early eighteenth century see Luigi Pepe, "Il calcolo infinitesimale in Italia agli inizi del secolo XVIII," Bollettino di Storia delle Scienze Matematiche, 1981, 1:43-101; Pepe, "Sulla trattatistica del calcolo infinitesimale in Italia nel secolo XVIII" (cit. n. 3); and Silvia Mazzone, and Chiara Roero, Jacob Hermann and the Diffusion of the Leibnizian Calculus in Italy (Florence: Olschki, 1997).

${ }^{39}$ For the correspondence with Riccati see Maria Laura Soppelsa, "Jacopo Riccati-Maria Gaetana Agnesi: Carteggio 1745-1751," Annali dell'Istituto e Museo di Storia della Scienza di Firenze, 1985, 10:117-159. The works Agnesi consulted are Guido Grandi, Quadratura circuli et hyperbolae per infinita hyperbolae \& parabolas geometrice exhibita (Pisa, 1703); Gabriele Manfredi, De constructione aequationum differentialium primi gradus (Bologna, 1707); Guillaume François de L'Hospital, Analyse des infiniment petits pour l'intelligence des lignes courbes (Paris, 1696); and Charles Reyneau, Analyse démontrée; ou, La méthode de résoudre les problèmes des mathématiques, 2 vols. (Paris, 1708).
} 
chose to write in the vernacular rather than in Latin, although the latter, she noted, "is believed by some to be more convenient to these matters." 40 Her style was clear and straightforward, providing the first complete systematic presentation of the Italian terminology for the concepts of calculus. Agnesi's fundamental didactic purpose and her teaching experience account for some of the original features of the book, such as the unusual care she took in explaining every single step of mathematical reasoning and her continuous effort to clarify mathematical concepts through examples from everyday life (e.g., she introduced negative and positive numbers through the analogy of debits and credits).

Another interesting feature of the text has to do with the choice of the contents. This should be understood with reference to Agnesi's specific purposes and priorities. Agnesi aimed to present modern analytical methods within the traditional framework of religious and metaphysical knowledge in order to enrich, not undermine, it. She needed a strategy to advance that purpose. We have already noted how devout natural philosophers like Manara dealt with "mixed mathematics." Unlike her tutor, Agnesi decided to concentrate on pure mathematics - which, in an essentially geometrical form, already occupied a central position in the traditional system of knowledge. Agnesi's basic move consisted in showing how the most recent developments in calculus could be understood in purely geometrical terms. Although Rampinelli and the Jesuit professors of Pavia had been lecturing on calculus, they had produced no textbooks along these lines. Their published works remained well within the framework of Euclidean synthetic methods. Agnesi, in contrast, provided a well-ordered presentation of the principles and methods of the theory of algebraic equations and of Cartesian geometry (in her first volume), followed by an introduction to differential calculus, integral calculus, and the integration of differential equations - which, referring to its historical origins, she called "the inverse method of tangents" (in her second volume). The topics of the second volume were presented as a "natural" continuation of the geometrical methods expounded in the first. ${ }^{41}$

Major changes were taking place in the practice of calculus when Agnesi wrote her book. Up to the 1730s, in spite of the well-known controversy between the Leibnizian and the Newtonian schools, translating mathematical works from the fluxional notation into the differential notation was a common practice and presented no particular problems. To be sure, those working in the Leibnizian framework were more interested in the algorithmic dimension of calculus and in its potential applications to a number of different fields, while the Newtonians emphasized the possibility of moving back to the geometrical meaning of their practice. From around 1730 the two approaches began to diverge radically, with the result that communication between the schools became more and more difficult. In strongholds of the Leibnizian tradition such as Basel and northern Italy, the algebraic algorithm of calculus developed rapidly in strict relation to specific applied concerns, mainly in dynamics, mechanics, and hydraulics. In Britain, on the other hand, the main concerns remained the geometrical meaning of the calculus and its application to celestial mechanics. As a result, during the eighteenth century the translation of Continental works into fluxional notation became increasingly difficult. Following the example of Euler and, later, Lagrange, and moving toward its progressive de-geometrization, Continental mathematicians

\footnotetext{
${ }^{40}$ Agnesi, Instituzioni analitiche (cit. n. 3), unpaginated introduction, [pp. 2-3, 5].

${ }^{41}$ For a "geometrical" interpretation of the Instituzioni analitiche along similar lines see Klens, Mathematikerinnen im 18. Jahrhundert (cit. n. 18), which includes a detailed description of the contents of the book (pp. 87-122) and a comparison of Agnesi's definition of "infinitesimal" with Euler's (pp. 129-133). On the contents of Agnesi's textbook see also Pepe, "Sulla trattatistica del calcolo infinitesimale in Italia nel secolo XVIII" (cit. n. 3).
} 
had completely transformed the practice of calculus by the end of the century. ${ }^{42}$ Characteristic features of the Continental calculus were the redefinition of the concept of "function" to include multivariate functions and partial derivatives and the central role assigned to the application of differential partial equations in the mathematization of mechanics.

The most prominent features of Agnesi's textbook arose from her decision not to embrace this Continental approach. First, as her textbook was based on an essentially geometrical conception of algebra and calculus, she placed great emphasis on techniques such as the geometrical construction of equations and on themes such as the geometrical meaning of infinitesimals. Agnesi devoted considerable attention to the methods and goals of Cartesian geometry, though this was perceived by many as rather old-fashioned. When she moved to the analysis of infinite quantities Agnesi acknowledged the relevance of recent works by Riccati, the Bernoullis, and Euler. Still, she continued to keep analytical formalism detached from mechanical and empirical considerations, in order to preserve the simplicity, rigor, and evidence she held to be distinctive of the classical tradition in geometry. Significantly, the historian of mathematics Jean Étienne de Montucla included Agnesi's Instituzioni analitiche in his list of works in the late seventeenth-century tradition of Cartesian analysis, noting that it shared their geometrical spirit. ${ }^{43}$

Second, despite the fact that leading Italian and foreign mathematicians were pursuing their studies on the calculus in order to investigate its applications to rational mechanics and experimental physics, not one example of the application of analytic methods to empirical problems can be found in the thousand pages of the Instituzioni analitiche. Agnesi considered the fundamental concepts and methods of algebra and calculus important primarily for their application to the solution of geometrical problems and to the study of interesting curves. One of the latter is the versiera, the curve that is most commonly associated with Agnesi's name and is known in the Anglo-Saxon literature as the "witch of Agnesi" (see Figure 3). In presenting the techniques of Cartesian analysis Agnesi studied the equation of this and other curves to determine the simplest laws for their generation. The versiera had attracted little attention in earlier treatises precisely because it could not be associated with any relevant mechanical or physical application. Its interest lay exclusively in its remarkable metric properties. ${ }^{44}$

\footnotetext{
${ }^{42}$ See Leonhard Euler's paradigmatic textbook Introductio in analysin infinitorum, 2 vols. (Lausanne, 1748). On the early development of calculus and the relations between the British and the Continental schools see Niccolò Guicciardini, The Development of Newtonian Calculus in Britain, 1700-1800 (Cambridge: Cambridge Univ. Press, 1989); and Guicciardini, Reading the Principia: The Debate on Newton's Mathematical Methods for Natural Philosophy from 1687 to 1736 (Cambridge: Cambridge Univ. Press, 1999).

${ }^{43}$ Jean Étienne de Montucla, Histoire des mathématiques, 4 vols. (1758; Paris, 1799-1802), Vol. 2, p. 169. On the perception of Cartesian geometry as old-fashioned see Henk Bos, "Arguments and Motivations in the Rise and Decline of a Mathematical Theory: The Construction of Equations, 1637-1750 ca.," Arch. Hist. Exact Sci., 1984, 30:331-380.

44 "Equazione alla curva da descriversi, che dicesi la Versiera": Agnesi, Instituzioni analitiche (cit. ì. 3), Vol. 1, p. 381. The word "witch" appeared in John Colson's translation, edited by John Hellins, in 1801; the phrase is rendered "which is vulgarly called the Witch": Agnesi, Analytical Intitutions, trans. Colson (cit. n. 3), p. 222. The Italian term "versiera" (Lat. "versoria"), coined by Guido Grandi in 1718, was translated by Colson and Hellins as "witch," perhaps because of an interesting confusion with the term "avversiera" ("she-devil"). In his notes to Galileo's "Trattato del moto naturalmente accellerato," Grandi had referred to "quella curva che io descrivo nel mio libro delle quadrature [1703], alla prop. IV, nata da' seni versi, che da me suole chiamarsi Versiera, in latino però Versoria." See Galileo Galilei, Opere, 3 vols., Vol. 3 (Florence, 1718), p. 393. One finds the new term in Lorenzo Lorenzini, Exercitatio geometrica (Florence, 1721): "sit pro exemplo curva illa, quam Doctissimus magnusque geometra Guido Grandus versoria nominat" (p. xxxi). On this issue see Mario Checchi, "Maria Gaetana Agnesi, Guido Grandi e la 'versiera," Atti e Memorie dell' Accademia Petrarca di Lettere, Arti e Scienze, 1982, 45:307-320; and Clifford Truesdell, "Corrections and Additions for Maria Gaetana Agnesi," Arch. Hist. Exact Sci., 1992, 43:385-386. For the later use of this curve in statistics see Stephen Stigler, "Cauchy and the Witch of Agnesi: An Historical Note on the Cauchy Distribution," Biometrika, 1974, 61:375-380.
} 


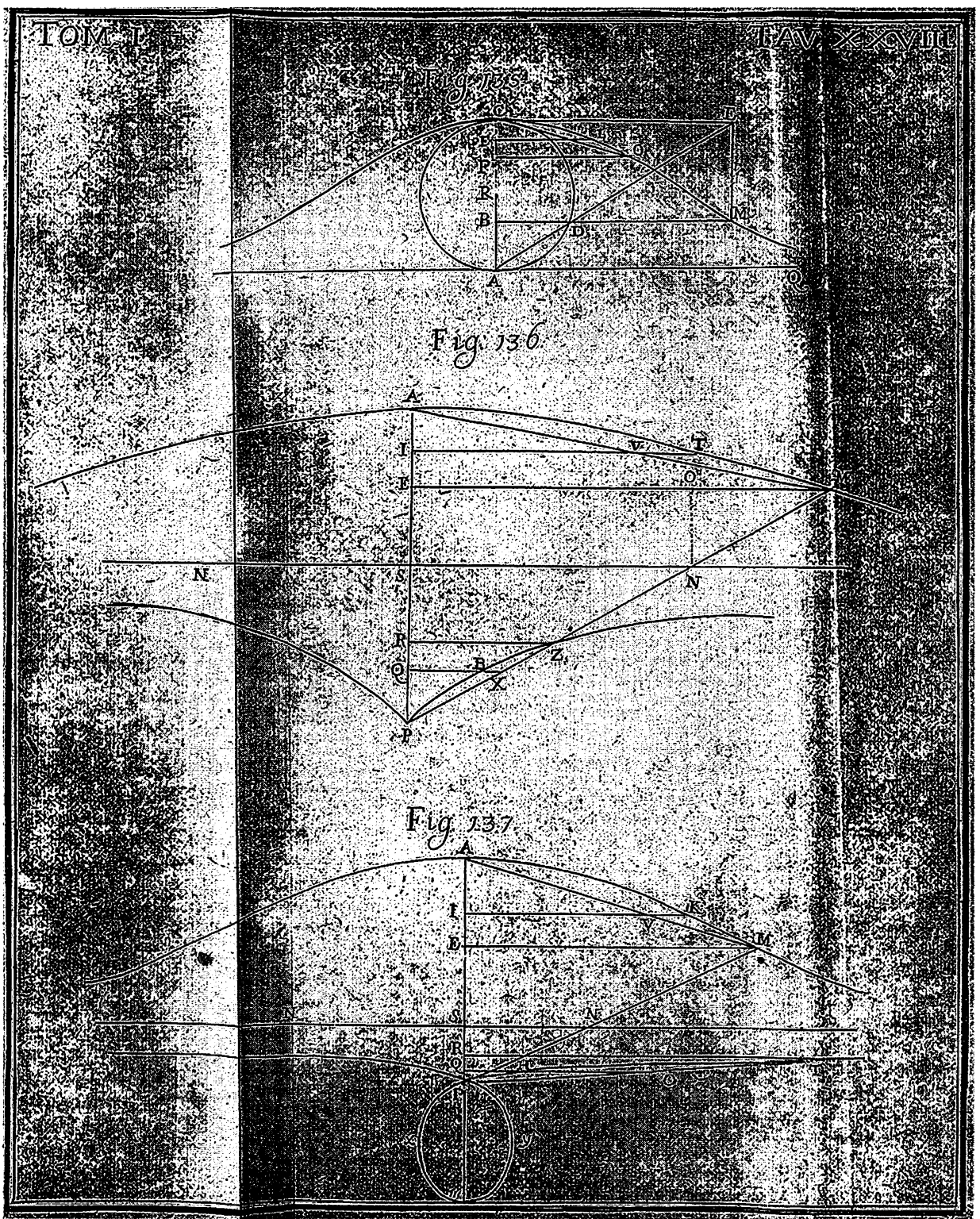

Figure 3. The curve at the top is the versiera, or, according to the Lucasian Professor John Colson, the "witch" of Agnesi. From Maria Gaetana Agnesi, Instituzioni analitiche (Milan, 1748), Volume 1, Table 28, Figure 135.

Truesdell noted these unusual features of Agnesi's approach: "while learning calculus, she does not wish to study rational mechanics as well!" He also pointed to an interesting passage in a letter Agnesi wrote to Jacopo Riccati. In response to his advice that she include the study of some curves relevant to mechanical problems in her text, she replied:

As for the squaring of the various curves mentioned by Your Excellency, I actually hadn't thought about many of them. However, the ones that depend on the knowledge of physics I 
left aside on purpose for, as Your Excellency has seen, I did not want to get involved with physical matters. I left aside all those problems that depend upon them, in order to avoid going beyond pure analysis, and its applications to geometry. ${ }^{45}$

These distinctive features of the textbook should be understood as deliberate choices made by Agnesi rather than as consequences of inadequate information or understanding. She believed that mathematics was the only field in which the human intellect could reach certainty; certainty derived from evidence; and evidence could be found in the (intellectual) perception of geometrical truths, not in the manipulation of algebraic algorithms. Given her metaphysical concerns and her geometrical approach to calculus, it is not surprising that Agnesi looked with interest at the mathematical textbooks of the French Oratorian tradition. In her preface Agnesi pointed to Charles Reyneau as her most influential precursor. Reyneau's is not one of the great names in the early history of calculus, and Truesdell considered this reference rather odd. "If we may judge by the opinions other mathematicians held of that book," he wrote, "in addition to her usual determination and industry she must have had a strong stomach." Most of those "other mathematicians" and historians have been rather dismissive of Reyneau's textbooks. Montucla, in his a posteriori reconstruction of the pioneering age of calculus, noted that "although quite good at its own time, [Reyneau's writing] was far too prolix"; furthermore, the examples he provided were "abstract, and without any application." 46

Reyneau had been working, like de L'Hospital, in the group of Oratorian mathematicians that gathered around Malebranche in the last two decades of the seventeenth century. At first they had defended Cartesian analysis; then they brought the discussion over the new analysis of Leibniz and the Bernoullis to France. Malebranche himself asked Reyneau to complete an introduction to Cartesian algebra and to the new calculus; the resulting works were Analyse démontrée (1708) and La science des grandeurs en general (1714), both addressed to the students of the College of the Oratory. The main goal was to present a complete introduction to Cartesian analysis and to explain the new infinitesimal techniques in terms of it. The theory of proportion was the unifying link that connected the old and new elements in his treatment, and the basic assumption was that geometry and algebra are different languages that describe the same objects: relations between magnitudes. The didactic relevance of mathematics was due to its certainty (deriving from the clarity and distinction of such ideas as number, extension, and magnitude) and to the heuristic value of the (Cartesian) analytic method, which "invariably takes us to the truth." Moreover, in the framework of the Malebranchian theory of knowledge, the practice of mathematics qua resolution of problems concerning magnitudes was invested with crucial metaphysical meaning. The eternal truths relative to the abstract features of geometrical extension were constitutive of the intelligibility of material objects and derived directly from the communion between the individual soul and God. Reyneau emphasized that the study of mathematics perfects the spirit of the believer because it refines a fundamental "spiritual quality," the "capacity of attention." 47 The "mind's attention," in this Malebranchean con-

\footnotetext{
${ }^{45}$ Truesdell, “Agnesi” (cit. n. 3), p. 133; and Maria Gaetana Agnesi to Jacopo Riccati, 1 Oct. 1746, in Soppelsa, "Riccati-Agnesi: Carteggio" (cit. n. 39), p. 128.

${ }^{46}$ Truesdell, “Agnesi," p. 124; and Montucla, Histoire des mathématiques (cit. n. 43), Vol. 2, p. 169.

${ }^{47}$ Reyneau is quoted in Jean Charles Juhel, "Le role des proportions dans l'evolution de l'ecriture algébrique au XVIİ̀me siècle," Sciences et Techniques en Perspective, 1984-1985, 8:57-162, on pp. 114, 115. For the texts see Reyneau, Analyse démontrée (cit. n. 39); and Charles Reyneau, La science des grandeurs en general, 2 vols. (Paris, 1714-1736). On the Oratorian group of mathematicians see Nicolas Malebranche, Oeuvres completes, 20 vols., Vol. 18, Pt. 2: Mathematica, ed. Pierre Costabel (Paris: Vrin, 1968).
} 
text, was a key concept that unified intellectual activity and religious meditation, being defined as both a "natural prayer" and the "occasional cause" of our knowledge. ${ }^{48}$

Consequently, although Reyneau recognized the utility of mathematics in applications such as ballistics and fortification, he devoted his attention mainly to the "other part" of mathematics, the one "abstract, and far from the senses," which contains "nothing other than speculative truths." 49 Malebranche's philosophical work and Reyneau's approach to calculus were targets for the contempt of the philosophes because of their Cartesianism and their attempt to integrate traditional metaphysical assumptions with modern science. The same features made Oratorian mathematics and didactics extremely attractive to Agnesi.

In conclusion, then, in her presentation of calculus Agnesi elaborated materials and styles from the northern Italian Leibnizian tradition but emphasized themes that were becoming extraneous to it. Although she adopted the differential notation, Agnesi declared that the "differential" was in fact equivalent to the Newtonian "fluxion"; she insisted on the priority of geometrical evidence; and she ignored the mechanical and hydraulic applications that were crucial to practitioners such as Giovanni Poleni (1683-1761), who succeeded Nicholas Bernoulli in the chair of mathematics at the University of Padua in 1719.

The peculiar position of Agnesi's textbook within Continental mathematics is highlighted by the circumstances of its English translation (1801), which took place in the context of the British debate over the nature of algebra and the foundations of calculus. For our present purposes it will be enough to remark that the promoters of the translation, the polymath Francis Maseres and the clergyman John Hellins, saw Agnesi's textbook as a valuable introduction to algebra and calculus in the Newtonian- "geometrical"- tradition. In fact, in the 1801 edition Agnesi's original differential notation was translated into fluxional notation. Far from signaling the penetration of recent Continental analysis in the British Isles, this Italian textbook was presented in opposition to those late eighteenth-century British authors who criticized fluxional calculus. In Agnesi's work, Hellins wrote, "algebra is judiciously applied to the higher geometry, which renders it an excellent introduction to the doctrine of fluxions." 50

\section{AGNESI ABANDONS MATHEMATICS}

In 1748 Lombardy emerged, ravaged, from years of war and political struggle. Economic crisis and social tensions had deepened further. While Senator Gabriele Verri gave voice to the ancient patriciate by denouncing the decadence of the Duchy of Milan and its inability to defend its traditions and political autonomy, repressive new laws were promulgated in response to increasing urban criminality. Approaching the conclusion of her mathematical work, Agnesi began to renegotiate the agreement with her father. She felt that a complete commitment to social activity should not be further delayed, but Pietro had other plans for his now-famous daughter. Determined to publish her mathematical

\footnotetext{
48 "Geometry, then, should be regarded as a kind of universal science that opens the mind, makes it attentive, and gives it the skill to control the imagination ...., and a controlled imagination sustains the mind's perception and attention": Nicolas Malebranche, The Search after Truth (1674), ed. and trans. Thomas M. Lemon and Paul J. Olscamp (Cambridge: Cambridge Univ. Press, 1997), p. 429.

${ }^{49}$ Ibid., p. 111.

${ }^{50}$ John Hellins, "Maria Gaetana Agnesi's Analytical Institutions," British Critic, 1804, 23:143-156 (quotation on p. 156), 24:653-660, 25:141-147. He described the British critics of fluxional calculus as "a cabal of sciolists, who endeavour to force themselves into the public notice by the misrepresentation and abuse of the most eminent authors" (ibid., 24:655).
} 
book in the best possible circumstances, he had even financed the installation of a printing press on the ground floor of his palazzo. This had afforded Maria Gaetana constant supervision over the typographers, who had never before worked with the symbols of differential and integral calculus.

Even before publishing her textbook, Agnesi had been invited to join a number of learned academies in Italy, including the Istituto delle Scienze in Bologna. After its publication, in 1748, she became famous. Letters of congratulation were sent by numerous personalities, including Laura Bassi, Jacopo Riccati, Giovanni Poleni, Etienne de Montigny (who read and commented very favorably on the book on behalf of the Académie Royale des Sciences), and the plenipotentiary minister Gian Luca Pallavicini, writing on behalf of the Empress Maria Theresa. Father François Jacquier-a protégé of Benedict XIV, a professor of physics at La Sapienza University, and coauthor of the translation of the Principia (1739-1742) that had legitimated Newton's natural philosophy in official Catholic culture-wrote from Rome. ${ }^{51}$ The pope himself sent Agnesi a personal letter of congratulation that showed some knowledge of the contents of her textbook. He also recommended that the University of Bologna appoint her lecturer in mathematics. Through his patronage, Benedict XIV was trying to consolidate the cultural hegemony of enlightened Catholicism while also granting Bologna-his home city-the honor of hosting two of the most learned Italian women-Bassi and Agnesi-and thus reinforcing the image of this Church-controlled university as a unique center of learning. ${ }^{52}$

Agnesi's fame was not spreading in academic circles alone. We also find reference to her, for instance, in Il medico olandese [The Dutch Physician], a comedy by the Venetian Carlo Goldoni, which was presented in Milan in 1756. Monsieur Guden, a "hypochondriac Pole," is waiting in the studio of a renowned physician. Carolina, a servant, enters the room, searching the shelves for a book. She explains to Guden that her young mistressthe niece of the physician-would like to read a book of analysis recently printed in Milan. Guden is surprised. "Do you find it surprising that my lady inclines to the sweet study of geometry?" asks Carolina. "You should rather marvel at the fact that a woman has given such a great book to the world. She is Italian, my lord, not Dutch, she is an illustrious and wise Lady, who brings honor to her country." Guden-more and more concerned-wonders what sort of woman the lady of such a servant can be..$^{53}$

\footnotetext{
${ }^{51}$ For the translation of Newton see Philosophiae naturalis principia mathematica, auctore Isaaco Newtono, eq. Aurato: Perpetuis commentariis illustrata communi studio pp. Thomae Le Seur \& Francisci Jacquier, 3 vols. (Geneva, 1739-1742). Documents pertaining to Agnesi's affiliation with the Accademia dei Filodossi of Milan (1734), the Accademia delle Scienze dell'Istituto di Bologna (June 1748), the Accademia degli Erranti of Fermo (1755), and the Accademia degli Indomiti of Bologna (1756) can be found in Biblioteca Ambrosiana, O.202.Sup.

${ }^{52}$ In his first letter, dated 21 June 1749, the pope congratulated Agnesi on the publication of the Instituzioni analitiche and claimed that the book "will improve the literary reputation of Italy and of our Academy of Sciences of Bologna." In a second letter, dated 10 Sept. 1750, he informed Agnesi of her appointment to a "lettura onoraria" at the University of Bologna. The diploma from the university is dated 5 Oct. 1750; it notes the position as "Cattedra di Pubblico Lettore di Matematica." Agnesi never went to Bologna to take up this teaching post. These documents are in Biblioteca Ambrosiana, O.202.Sup. On the presence of learned women at the University of Bologna and the patronage of Benedict XIV see Marta Cavazza, "'Dottrici' e lettrici dell' università di Bologna nel Settecento," Annali di Storia delle Università Italiane, 1997, 1:109-126. See also Alma Mater Studiorum: La presenza femminile dal XVIII al XX secolo: Ricerche sul rapporto donna/cultura universitaria nell'ateneo bolognese (Bologna: Clueb, 1988), which includes a short article on Agnesi and a list of her published and manuscript scientific writings: Carla Vettori Sandor, "L'opera scientifica ed umanitaria di Maria Gaetana Agnesi," pp. 105-118.

53 "Stupitevi piuttosto che con saper profondo/Prodotto abbia una donna un sì gran libro al mondo./È italiana l'autrice, signor, non è olandese,/Donna illustre, sapiente, che onora il suo paese": Carlo Goldoni, Il medico olandese, in Opere complete, 41 vols., Vol. 14 (Venice: Tipografia dell'Istituto Veneto di Arti Grafiche, 1912), pp. 9-95, on pp. 22-23.
} 
After 1748 an increasing number of visitors asked to see Agnesi at the palazzo, and more and more questions and essays were submitted for her comments. As late as 1762 the works of young mathematicians from the Academy of Sciences of Turin, including Giuseppe Luigi Lagrange, were sent to the Palazzo Agnesi for comments and encouragement. ${ }^{54}$ Unimpressed by the eulogies and the new opportunities, Agnesi reluctantly agreed to meet some visitors and to reply to a few letters. She also appeared in the salon of the palazzo for occasional soirées, mostly to play the cello along with her sister. In return, her father conceded that she might use some rooms of the palazzo to host those she assisted. The death of Pietro, in March 1752, signaled a turn in the lives of both sisters. Maria Teresa married Pietro Antonio Pinottini, from a family of the minor nobility, whom her father clearly disliked; it is perhaps noteworthy that she got married in June 1752, in the middle of the prescribed six-month period of mourning. For Maria Gaetana Pietro's death meant that she could abandon their compromise and devote herself completely to pious work.

Among the last documents pertaining to Agnesi's scientific activity are letters from 1750 addressed to Antonio Frisi and to his brother Paolo (1728-1784), a Milanese mathematician and natural philosopher. Paolo Frisi had asked Agnesi to read and comment on his mathematical dissertation on the physical reasons for the present shape of the earth. In her response to Paolo Agnesi declined to offer an opinion, alleging incompetence. Writing more sincerely to her friend Antonio, she noted that she much respected Paolo's "deep thinking" but admitted, "To tell you the truth I couldn't advise him to publish his work." Agnesi thought that Paolo was dealing with "a very difficult matter," and she believed that he had treated it in such a way as to compromise the "honor of religion." Other zealous clergymen shared her view: Frisi's superiors in the Barnabite order denied the "imprimatur" to the essay, and it was published with private funds. ${ }^{55}$

Through the early physical-mathematical research of Paolo Frisi, as through Corio's sensationalist and hedonist essays, Agnesi came in contact with the more radical currents of the Lombard Enlightenment. Frisi's main target was the work of the Jesuit natural philosopher Rudjer Boscovich. Agnesi must have felt little sympathy for Frisi's mathematizing rationalism, which was grounded in a belief in the truly cognitive function of mathematical analysis, conceived as the privileged tool for the investigation of empirical reality. Boscovich, whose views were closer to Agnesi's own, had never conceded such autonomous legitimacy to mathematical formalism and formulated a philosophy of nature in an essentially geometrical form. ${ }^{56}$

\footnotetext{
${ }^{54}$ Luigi Wicardel, marquis de Fleury, a patron and founder of the Turin academy, sent Agnesi a volume of its Acts, so that "nos jeunes Academicies puissant se vanter d'etre connus de vous; et profiter même de vos utiles avis": quoted in Frisi, Elogio di Agnesi (1799), p. 79. See Mélanges de philosophie et de mathématique de la Société Royale de Turin pour les années 1760-1761 (Turin, 1762).

${ }_{55}$ Biblioteca Ambrosiana, Y.150.Sup, fol. 125r. The essay was published thanks to the support of Count Donato Silva: Paolo Frisi, Disquisitio mathematica in caussam physicam figurae et magnitudinis telluris nostrae (Milan, 1751).

${ }^{56}$ Pietro Redondi, "Cultura e scienza dall'illuminismo al positivismo," in Storia d'Italia-Annali 3: Scienza e tecnica nella cultura e nella società dal Rinasciemto ad oggi, ed. Gianni Micheli (Turin: Einaudi, 1980), pp. 685-814, esp. pp. 685-697. On the varied scientific production of Paolo Frisi see also Gennaro Barbarisi, ed., Ideologia e scienza nell'opera di Paolo Frisi, 2 vols. (Milan: Franco Angeli, 1987). On Boscovich and the reform of Jesuit culture in the eighteenth century see Ugo Baldini, "Boscovich e la tradizione gesuitica in filosofia naturale: Continuità e cambiamento," Nuncius, 1992, 7:3-68. For an overview of the new cultural and scientific policy of the Habsburgs see Maria Teresa Monti, "Promozione del sapere e riforma delle istituzioni scientifiche nella Lombardia austriaca," in La politica della scienza: Toscana e stati italiani nel tardo Settecento, ed. Giulio Bersanti, Vieri Becagli, and Renato Pasta (Florence: Olschki, 1991), pp. 367-392.
} 
Agnesi did not enter the heated debates that characterized the Lombard and Italian Enlightenment during the second half of the century. In 1752 she renounced her rights to the family estate in exchange for an annuity that allowed her to host an increasing number of women in need and to devote all her time to their assistance. In 1759 she left the palazzo, moving to a more modest apartment nearby where she continued her catechistic activity and her volunteering at the Ospedale Maggiore. She worked with women from the urban lower classes, providing help and education to orphans, prostitutes, the elderly, the sick, and the mentally ill. Agnesi wanted to offer all of them the opportunity to embrace faith, whether to rescue them for dignified, useful lives or to enlighten the last part of their earthly paths. In 1771 a new charitable institution to assist the urban poor, the Pio Albergo Trivulzio, was opened in Milan. Archbishop Pozzobonelli asked Agnesi to become the director of the female department, which eventually housed about 450 patients. ${ }^{57}$ By that time all requests for comments, invitations, and offers of affiliation were met with a simple card in which Agnesi politely pointed out that her new administrative and catechistic duties absorbed her completely.

In 1783 Agnesi, who meanwhile had renounced all her possessions and was living in poverty, moved to the Pio Albergo Trivulzio to be closer to those she assisted. There she died of pneumonia in January 1799. Milanese authorities paid little attention to Agnesi's death, as war was again ravaging northern Italy. Her body was buried in a mass grave outside of Porta Romana, the southern gate of the town. Frisi tells us that, to those few who managed to contact her in her later years, Agnesi explained: "Man always acts to achieve goals; the goal of the Christian is the glory of God. I hope my studies have brought glory to God, as they were useful to others, and derived from obedience, because that was my father's will. Now I have found better ways and means to serve God, and to be useful to others." 58

\section{CONCLUDING REMARKS}

Well before the high season of the Italian Enlightenment, which is usually associated with the administrative reforms of the second half of the eighteenth century, modern mathematics and experimental methodologies found supporters in Milan. These were primarily local exponents of the Catholic Enlightenment who intended to promote modern scientific culture within the framework of the traditional Catholic system of knowledge. Maria Gaetana Agnesi was a protagonist of this cultural movement. In her Instituzioni analitiche she presented the most complete introduction to algebra, analytic geometry, and differential and integral calculus yet published in Europe. Far from being a tool to subvert traditional metaphysical assumptions and religious dogmas, Agnesi thought of mathematical analysis as an intellectual practice that could play an important role in the spiritual life of the believer. A satisfactorily historical assessment of Agnesi's textbook requires the attribution of causal relevance to her intentions and purposes and a careful consideration of the cultural and institutional resources she could rely upon. To "explain" the distinctive features of

\footnotetext{
57 On the Pio Albergo Trivulzio see Emilio Gucciardini, Il Pio Albergo Trivulzio nella storia e nell'attualità, 1771-1961 (Milan: [Pio Albergo Trivulzio], 1961); Carlo Capra, "Il Pio Albergo Trivulzio: Un'eredità del secolo dei lumi," in La nascita del Pio Abergo Trivulzio: Orfani, vecchi e poveri a Milano tra Settecento e Ottocento (Milan: Electa, 1993), pp. 13-19; and Giorgio Cosmacini, I vecchi e la cura: Storia del Pio Albergo Trivulzio (Rome: Laterza, 1994).

${ }^{58}$ Frisi, Elogio di Agnesi (1799), p. 70.
} 
her textbook entails expounding them in terms of their historical causes, not just referring to an allegedly linear development of eighteenth-century calculus.

Further research should be devoted to the specific sociocultural conditions that made it possible for a few women to enter academies and universities in late seventeenth- and early eighteenth-century Italy. Londa Schiebinger notes that "Italy was an exception in Europe, and little is known about why women professors were acceptable to the church and university." Paula Findlen has already highlighted the long-forgotten role of women in post-Galilean Italian science. Her study of Laura Bassi shows that Italian academic institutions, unlike their French and English counterparts, were places where talented women could "negotiate their way through the scientific networks." 59 Through various biographical reconstructions, Findlen has also shown how the basic pattern of the career of the Italian filosofesse could vary with local contingencies. This study of Maria Gaetana Agnesi aims to be a contribution to exploration of such variables. A wealthy family eager for social enhancement, a Church eager for new charismatic figures, and a reformist religiosity characterized by favorable views about the education of women and intellectual achievement: these were the conditions that made it possible for Agnesi to establish herself as a legitimate author of a mathematical treatise and as an advisor to the archbishop of Milan on theological matters. It can be suggested that the same religious reformism was a factor in the achievements of other eighteenth-century learned women, like Laura Bassi or Cristina Roccati. Reference to the Catholic Enlightenment can therefore provide a partial answer to the question of the Italian "anomaly" in the European context of the eighteenth century. Indeed, the radicalization of the cultural debate in the second half of the century and the decline of the moderate Muratorian reformist position within the Church coincided with the decline in the presence of women in Italian scientific institutions and with what Findlen describes as the gradual "domestication" of upper-class Italian women. By the end of the century, the cultural factors and the specific interests that had created the conditions for talented women to access privileged forms of knowledge and social life had disappeared. It would be a long time before a woman would again be offered a chair at a European university. ${ }^{60}$

\footnotetext{
${ }^{59}$ Londa Schiebinger, The Mind Has No Sex? Women in the Origins of Modern Science (Cambridge, Mass.: Harvard Univ. Press, 1989), p. 16 (this text is also useful for contextualizing the Italian cases within the broader European framework); and Findlen, "Science as a Career in Enlightenment Italy" (cit. n. 18). On Bassi's scientific activity see also Marta Cavazza, "Laura Bassi e il suo gabinetto di fisica sperimentale: Realtà e mito," Nuncius, 1995, 10:715-753. The network of power relations in which Bassi acted is explored in Ceranski, "Und sie fürchtet sich vor niemandem" (cit. n. 18).

${ }^{60}$ Paula Findlen, "Translating the New Science: Women and the Circulation of Knowledge in Enlightenment Italy," Configurations, 1995, 2:167-206; see p. 204 on "domestication." Findlen noticed that learned women were perceived as "passive" manipulators of knowledge, being engaged primarily in its transmission and popularization. This judgment is reflected in recent historiography, which has largely ignored the role of the filosofesse in the context of eighteenth-century Italian culture. In fact, as we have seen in the case of Agnesi, systematization and popularization were far from being "passive" enterprises. On the persistence of the myth of Laura Bassi in Bologna see Cavazza, "Laura Bassi."
} 